\title{
The Effectiveness and Cost-Effectiveness of Hepatitis C Screening for Migrants in the EU/EEA: A Systematic Review
}

\author{
Christina Greenaway ${ }^{1,2,3, *}$, Iuliia Makarenko ${ }^{2}$, Claire Nour Abou Chakra ${ }^{4}$, \\ Balqis Alabdulkarim ${ }^{2}$, Robin Christensen ${ }^{5}$, Adam Palayew ${ }^{3}$, Anh Tran ${ }^{6}$, Lukas Staub ${ }^{6}(\mathbb{D}$, \\ Manish Pareek ${ }^{7}$, Joerg J. Meerpohl ${ }^{8}{ }^{\circledR}$, Teymur Noori ${ }^{9}{ }^{\circledR}$, Irene Veldhuijzen ${ }^{10}$, Kevin Pottie ${ }^{11,12}$, \\ Francesco Castelli ${ }^{13,+, \ddagger}$ and Rachael L. Morton ${ }^{6}$
}

1 Division of Infectious Diseases, Jewish General Hospital, McGill University, Montreal, QC H3T 1E2, Canada

2 Centre for Clinical Epidemiology of the Lady Davis Institute for Medical Research, Jewish General Hospital, Montreal, QC H3T 1E2, Canada; makarenko.j@gmail.com (I.M.); Balqis.alabdulkarim@mail.mcgill.ca (B.A.)

3 Department of Epidemiology, Biostatistics, and Occupational Health, McGill University,

Montreal, QC H3A 1A2, Canada; apalayew@gmail.com

4 Department of Microbiology and Infectious Diseases, Université de Sherbrooke, Sherbrooke, QC J1H 5N4, Canada; Claire.Nour.Abou.Chakra@USherbrooke.ca

5 Musculoskeletal Statistics Unit, The Parker Institute, Bispebjerg and Frederiksberg Hospital \& Department of Rheumatology, Odense University Hospital, DK2000 Odense, Denmark; Robin.Christensen@regionh.dk

6 NHMRC Clinical Trials Centre, The University of Sydney, Sydney 1450, Australia; anh.tran@ctc.usyd.edu.au (A.T.); lukas.staub@ctc.usyd.edu.au (L.S.);

Rachael.morton@ctc.usyd.edu.au (R.L.M.)

7 Department of Infection, Immunity and Inflammation, University of Leicester, Leicester LE1 7RH, UK; manish.pareek@leicester.ac.uk

8 Institute for Evidence in Medicine (for Cochrane Germany Foundation), Medical Center, University of Freiburg, 79110 Freiburg, Germany; meerpohl@ifem.uni-freiburg.de

9 European Centre for Disease Prevention and Control, 16973 Solna, Sweden; teymur.noori@ecdc.europa.eu

10 Centre for Infectious Disease Control, National Institute for Public Health and the Environment (RIVM), 3720 BA Bilthoven, The Netherlands; irene.veldhuijzen@rivm.nl

11 C.T. Lamont Primary Health Care Research Centre, Bruyère Research Institute, Ottawa, ON K1N 5C8, Canada; kpottie@uottawa.ca

12 Centre for Global Health, University of Ottawa, Ottawa, ON K1N 5C8, Canada

13 Division of Infectious Diseases, University of Brescia, 255123 Brescia, Italy; francesco.castelli@unibs.it

* Correspondence: ca.greenaway@mcgill.ca; Tel.: +1-514-340-8222; Fax: +1-514-340-7546

+ UNESCO Chair holder "Training and empowering human resources for health development in resource-limited countries".

$\ddagger \quad$ The authors are responsible for the choice and presentation of views contained in this article and for opinions expressed therein, which are not necessarily those of UNESCO and do not commit the Organization.

Received: 17 July 2018; Accepted: 10 September 2018; Published: 14 September 2018

check for updates

\begin{abstract}
Chronic hepatitis C (HCV) is a public health priority in the European Union/European Economic Area (EU/EEA) and is a leading cause of chronic liver disease and liver cancer. Migrants account for a disproportionate number of HCV cases in the EU/EEA (mean $14 \%$ of cases and $>50 \%$ of cases in some countries). We conducted two systematic reviews (SR) to estimate the effectiveness and cost-effectiveness of HCV screening for migrants living in the EU/EEA. We found that screening tests for HCV are highly sensitive and specific. Clinical trials report direct acting antiviral (DAA) therapies are well-tolerated in a wide range of populations and cure almost all cases (>95\%) and lead to an $85 \%$ lower risk of developing hepatocellular carcinoma and an $80 \%$ lower risk of all-cause mortality. At 2015 costs, DAA based regimens were only moderately cost-effective and as a result less than $30 \%$ of people with HCV had been screened and less $5 \%$ of all $\mathrm{HCV}$ cases had been treated
\end{abstract}


in the EU/EEA in 2015. Migrants face additional barriers in linkage to care and treatment due to several patient, practitioner, and health system barriers. Although decreasing HCV costs have made treatment more accessible in the EU/EEA, HCV elimination will only be possible in the region if health systems include and treat migrants for HCV.

Keywords: hepatitis C; screening; migrants; viral hepatitis elimination; European Union

\section{Introduction}

Chronic hepatitis $\mathrm{C}$ is an important public health problem in the EU/EEA, with an estimated 3.24 million persons having active hepatitis $C$ virus $(\mathrm{HCV})$ infection $[1,2]$. It is a leading cause of chronic liver disease and liver cancer in the EU/EEA due to undetected and untreated infections [3-5]. Since 2013, the landscape of HCV treatment has changed rapidly as pan-genotypic DAA HCV treatment regimens that cure most infections ( $>95 \%$ of cases) have become available, making HCV elimination possible [6-9]. In 2015 however, only $34 \%$ of HCV infected persons had been diagnosed and less than $5 \%$ of all $\mathrm{HCV}$ cases had been treated [2]. Identifying and treating all groups at risk for HCV in the EU/EEA will be essential to address the health and economic burden due to HCV in the EU/EEA and to reach WHO elimination goals by 2030 [3,5,9-11].

$\mathrm{HCV}$ screening and control programs in the EU/EEA primarily focus on persons who inject drugs (PWID), as they are the largest and highest burden population [1]. Migrants from intermediate and high $\mathrm{HCV}$ prevalence countries (anti-HCV $\geq 2 \%$ and $\geq 5 \%$, respectively) are an additional important and underappreciated group at increased HCV risk in the EU/EEA and often do not have identifiable HCV risk factors [12,13]. They are most likely to have been exposed to HCV in their countries of origin through receipt of contaminated blood products or unsafe injections or procedures, and have a prevalence of $\mathrm{HCV}$ that reflects that of their countries of origin [14,15]. The increased flow of migrants from intermediate and high HCV prevalence countries into the EU/EEA over the past few decades has resulted in a disproportionately high number of reported HCV cases (14\%) occurring among migrants, who account for up to one half of all cases in some low HCV prevalence EU/EEA countries [12,13]. HCV diagnosis among migrants living in low incidence countries is delayed due to several patient, practitioner, and infrastructural barriers that may result in a higher burden of liver-associated complications compared to host populations [16,17]. We conducted a systematic review (SR) to estimate the effectiveness, resource use, costs, and cost-effectiveness of HCV screening programs for migrants in the EU/EEA.

\section{Methods}

\subsection{Overall Approach and Key Questions}

Using the Grading of Recommendations Assessment, Development, and Evaluation (GRADE) approach, the Campbell and Cochrane Collaboration Equity Methods Group and review team including clinicians, public health experts and researchers from across the EU/EEA, we conducted evidence syntheses. "Migrants", a focus of this review, included asylum seekers, refugees, undocumented migrants, and other foreign-born residents. A detailed description of the methods have been published and were registered in PROSPERO (CRD42016045798) [18].

We used the GRADE approach to rate the certainty of evidence starting with a simplified categorization of study types (i.e., meta-analyses, RCTs, and observational studies). The rating scheme allows for factors that may raise or lower the level of certainty. Factors that lower certainty of evidence include, risk of bias, inconsistency across studies, indirectness, and publication bias. Factors that increase certainty of evidence include large effect size and an observed dose-response effect. The final certainty ratings are reflective of the certainty in the estimated effect in the context of 
bias and limitations. Evidence was graded as high, moderate, low, or very low certainty, based on how likely further research would change the confidence in the estimate of effect. Low certainty and very low certainty do not mean absence of evidence for effectiveness, but rather signal highlights the need for more research to improve the precision of the estimate of effect.

This review followed the Grading of Recommendations Assessment, Development, and Evaluation (GRADE) and Cochrane methodological approach [18]. We used the Preferred Reporting Items for Systematic Reviews and Meta-Analyses (PRISMA) Checklist for reporting the results of the systematic reviews (SR) $[18,19]$. The review team developed two overarching research questions (PICO: Population, Intervention, Comparison, Outcome) and a logic model (Figure S1). The logic model showed key questions/concepts along the evidence chain along the screening effectiveness pathway $[18,20,21]$. The two overarching research questions (PICO) we sought to answer were:

- What is the effectiveness of screening migrants arriving and living in the EU/EEA for HCV?

- What is the cost, resource utilization, and cost-effectiveness for screening migrants for HCV?

The following key questions were identified along the screening effectiveness pathway. (1) What is the test accuracy and performance characteristics of screening tests for HCV? (2) What is the efficacy of new direct acting antiviral (DAA) treatments for HCV to decrease HCV associated morbidity and mortality? (3) What is the uptake of HCV of screening and treatment? (4) What is the cost-effectiveness of a screen-treat approach for $\mathrm{HCV}$ in the general population and the migrant population when treated with DAAs? [18].

\subsection{Search Strategy and Selection Criteria}

We conducted two searches, one for SRs and guidelines on the effectiveness and cost-effectiveness of HCV screening programs in migrants and a second search for SRs and primary studies on the resource use, costs, and cost-effectiveness of HCV screening programs in migrants. For the first search, Medline via OVID, EMBASE, CINAHL, Epistemonikos, and Cochrane CENTRAL were searched for publications between 1 January 2010 and 12 May 2016. A combination of key terms was used including "hepatitis C/HCV", "screening", "migrants", "costs", "cost-effectiveness" AND "guidelines", and "reviews". The search terms and the search strategy for Ovid Medline are included in the supplementary material (Table S1). We also searched grey literature websites for published guidelines and reports at CDC, ECDC, EASL (European Association for the Study of the Liver), and WHO. We applied no language restrictions to the search. In the second search, using terms of "hepatitis C/HCV", "screening", "costs", and "cost-effectiveness", Medline via Ovid, EMBASE, the NHS Economic Evaluation Database (NHS EED), Database of Abstracts of Reviews of Effects (DARE), and the Cost Effectiveness Analysis Tufts registry and Google scholar databases were searched for publications between 1 January 2000 and 31 May 2016. Reference lists of relevant reviews were also searched.

\subsection{Study Selection and Quality Assessment}

Two authors screened the titles and abstracts, assessed selected full-text articles for eligibility, and extracted data from included articles. Disagreements were resolved by consensus or by a third author. For the screening effectiveness search we included systematic reviews on the impact of HCV screening or antiviral therapies on the development of liver related morbidities such as cirrhosis, hepatocellular carcinoma, and the need for liver transplantation and all-cause or attributable mortality. For the cost-effectiveness search we included individual economic studies of screening strategies that included an arm of direct acting antiviral (DAA) therapies or studies of the cost-effectiveness of DAA therapies [8]. We only included studies published in full and in English or French. If more than one version of a SR was identified, the most recent was considered. Studies were excluded if they focused only on nongeneralizable subgroups (such as PWIDs) (Figures 1 and 2). 


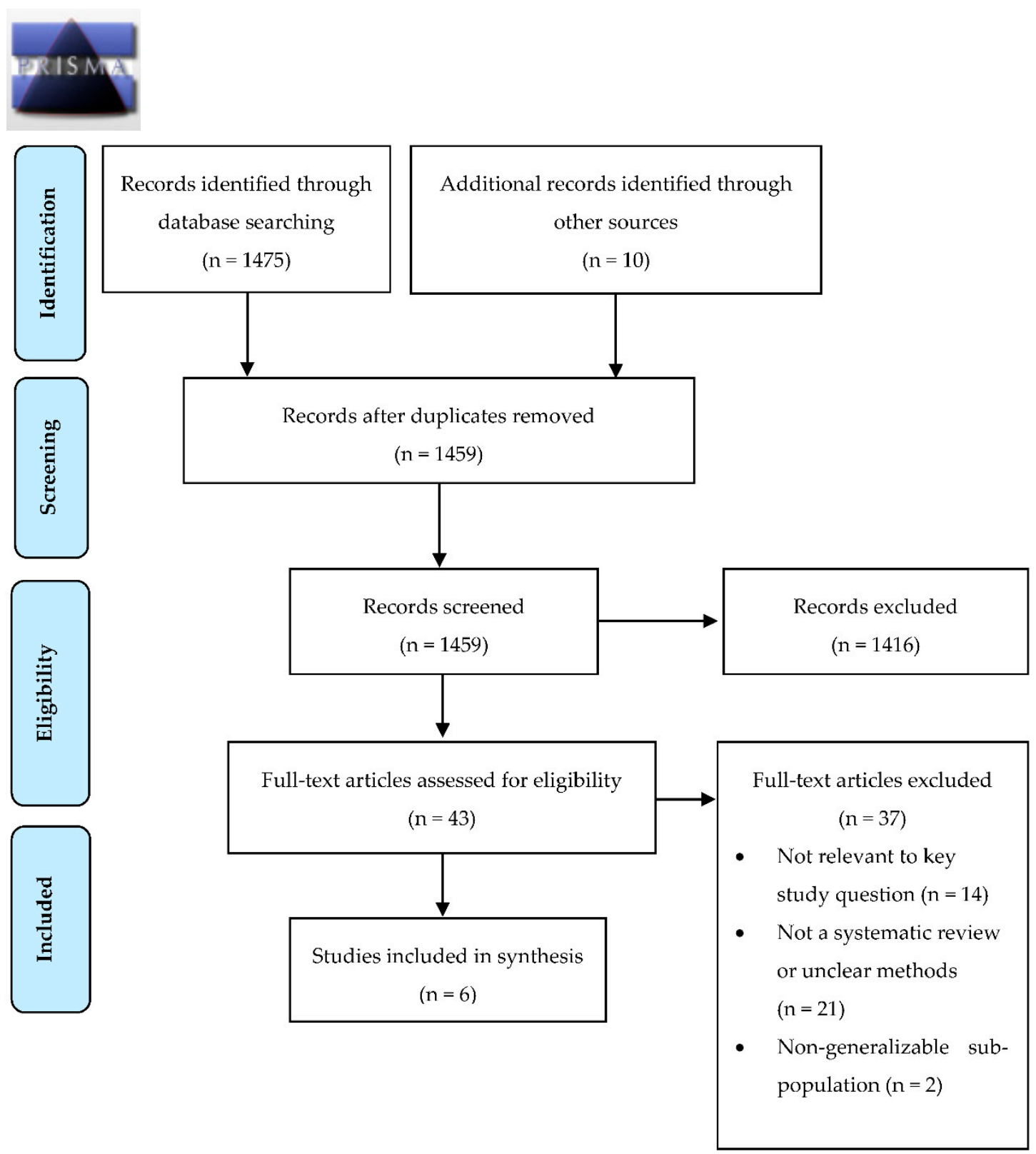

Figure 1. Preferred Reporting Items for Systematic Reviews and Meta-Analyses (PRISMA) diagram for the effectiveness of hepatitis $C$ screening. 


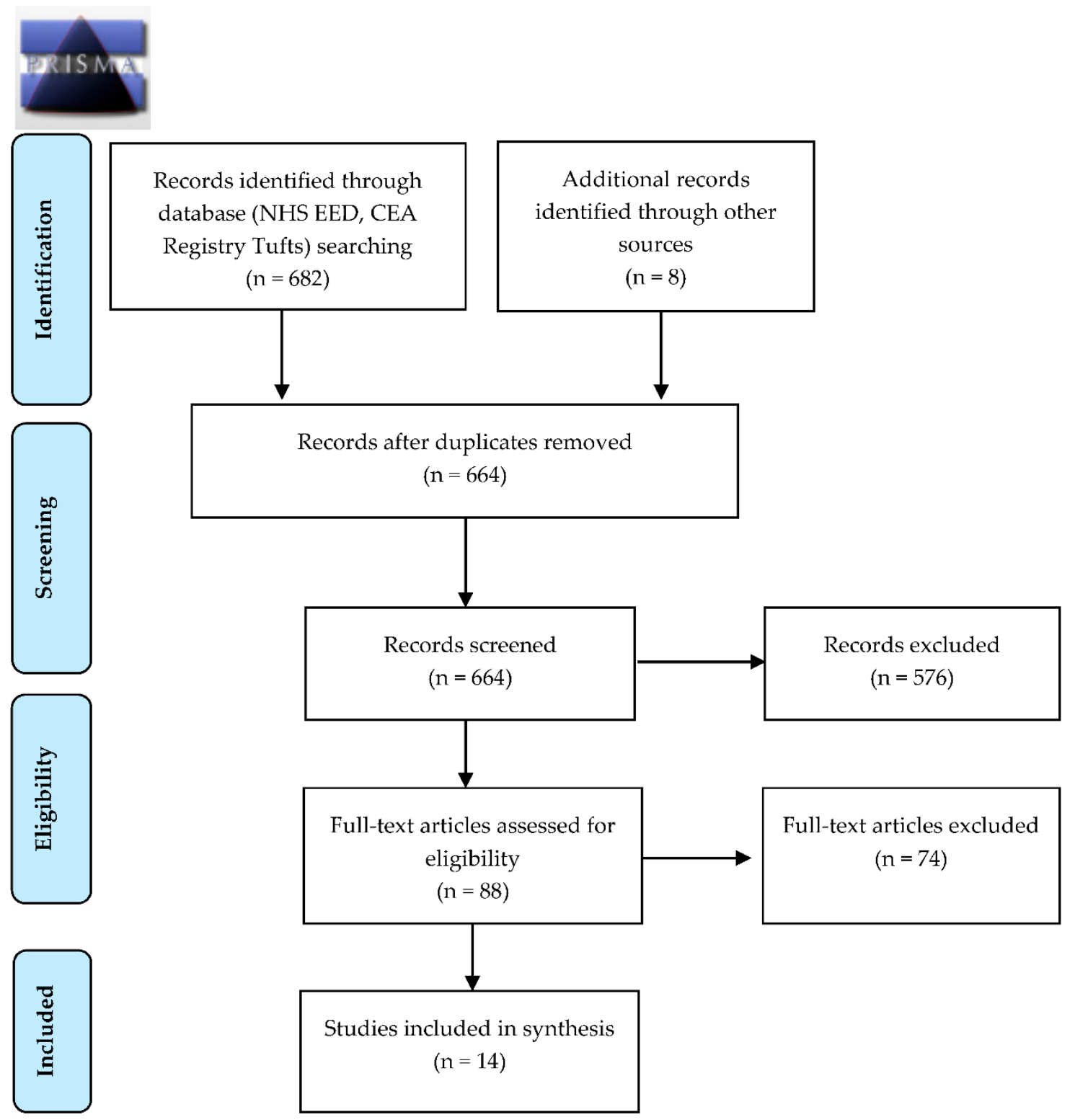

Figure 2. PRISMA diagram for the resource use, costs, and cost-effectiveness for hepatitis C screening.

The methodologic quality of SRs was assessed by two authors using the AMSTAR tool (A Measurement Tool to Assess Systematic Reviews) [22]. The GRADE criteria were applied to assess the certainty of evidence in preselected outcome measures in the SRs (GRADE Tables S2-S5) [23]. For the second search which included individual studies the certainty of economic evidence in each study was assessed using the relevant items from the 1997 Drummond checklist [24].

\subsection{Data Extraction and Synthesis}

The following information was extracted from each study: study design, objectives, analyses, quality of the individual studies included in the systematic review, population examined, number of included studies, total number of participants included, intervention, outcome, and the results. For the economic studies we extracted the following data; economic methods used (e.g., microcosting study, within-trial cost-utility analysis, Markov model), description of the case base population, the intervention and comparator, absolute size and relative difference in resource use, cost-effectiveness results (e.g., incremental net benefit (INB) or incremental cost-effectiveness ratio (ICER)), and three specific questions for the GRADE Evidence to Decision table: the size of the resource requirements, 
the certainty of evidence around resource requirements, and whether the cost-effectiveness results favored the intervention or comparison [25]. Key results were converted to 2015 Euros using the Cochrane web-based currency conversion tool: https:/ / eppi.ioe.ac.uk/costconversion/default.aspx.

\section{Results}

\subsection{Search Results}

In the search for the effectiveness of HCV screening we retrieved 1475 references and identified 10 additional records through other sources (Figure 1). After duplicates were removed, 1459 references were screened by title and abstract. A total of 43 references were then selected for full text assessment. We did not identify any randomized controlled trials or SRs on the effectiveness of HCV screening in the general or migrant populations. We therefore included five SRs and one guideline that addressed the key questions along the screening evidence chain: the performance of HCV diagnostic tests $(n=2)[6,26]$, the impact of HCV treatment on preventing HCC and all-cause mortality $(n=3)$ [27-29], and the HCV care continuum $(n=1)$ (Table 1) [30]. In the economic search, 682 articles were retrieved and an additional eight records identified through other sources (Figure 2). After duplicate removal, 664 references were screened by title and abstracts. Of these, a total of 88 references underwent full text assessment and 14 individual studies of populations living in low HCV prevalence countries were included (Table 2) [31-44].

\subsection{Performance of Diagnostic Tests}

The performance of diagnostic testing for HCV has been recently summarized in the 2017 WHO Guidelines on Hepatitis B and C testing [6]. WHO estimates the sensitivity and specificity of 3rd generation HCV enzyme immunoassays (EIA) to be $98 \%$ and $99 \%$, respectively [6]. Similarly, the sensitivity of the confirmatory test to detect virus nucleic acid (nucleic acid test; NATs) is estimated to be $96.2 \%$ (95\% CI, 94.4-97.5) and the specificity to be $98.9 \%$ (98.3-99.3) [6]. There was no reported evidence suggesting that migrants or any other group would encounter lower performance rates. The accuracy of point of care testing, a strategy that potentially could increase screening uptake, was reviewed by Khuroo et al. who found that these tests performed well in low, middle, and high income countries [26]. The sensitivity (95.8\% (93.9-97.1)) was slightly lower compared to EIAs but demonstrated comparable specificity (99.0\% (98.5-99.3)) [26]. The GRADE certainty of the evidence in the Khuroo study was very low (S3 GRADE Table 1). 
Table 1. Characteristics of studies on the effectiveness of hepatitis $C$ screening.

\begin{tabular}{|c|c|c|c|c|c|}
\hline Study & $\begin{array}{l}\text { Quality of Systematic } \\
\text { Review/GRADE } \\
\text { Certainty of Evidence }\end{array}$ & Design & Population & Intervention/Outcomes & Results \\
\hline $\begin{array}{l}\text { Khuroo } \\
2015 \text { [26] }\end{array}$ & $\begin{array}{l}\text { Quality of systematic } \\
\text { Review } \\
\text { AMSTAR: } 8 / 11 \\
\text { GRADE Certainty of } \\
\text { Evidence } \\
\text { Very Low }\end{array}$ & $\begin{array}{l}\text { Systematic Review } \\
\text { Up to March 2012. } \\
\text { N = 30 studies: } \\
\text { 25-full-text article } \\
\text { 2-WHO reports } \\
\text { 1-WHO draft report } \\
\text { 2-letters to editor }\end{array}$ & 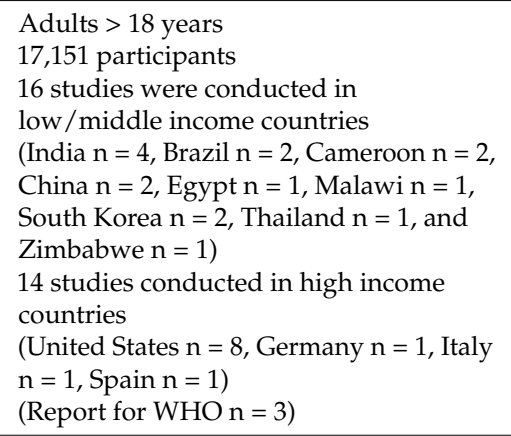 & $\begin{array}{l}\text { Intervention: } \\
\text { Point-of-care test: any commercially } \\
\text { available assay at or near the site of } \\
\text { patient care with }<30 \text { min } \\
\text { turn-around time. Reference } \\
\text { standard: third generation EIA, } \\
\text { microenzyme immunoassay, CIA, } \\
\text { RIBA, NAT } \\
\text { Outcome: } \\
\text { Sensitivity, specificity, LR+/-, } \\
\text { Diagnostic OR }(95 \% \text { CI })\end{array}$ & $\begin{array}{l}\text { Pooled sensitivity: } 97.4 \%(95 \% \\
\text { CI = 95.9-98.4) } \\
\text { specificity: } 99.5 \% \text { (99.2-99.7) } \\
\text { +LR: } 80.17 \text { (55.35-116.14) } \\
\text {-LR: } 0.03 \text { (0.02-0.04) } \\
\text { Diagnostic OR: } 3032.85 \\
\text { (1595.86-5763.78) } \\
\text { OraQuick test had the highest } \\
\text { sensitivity and specificity: } \\
\text { sensitivity: } 99.5 \text { (98.9-99.8) } \\
\text { specificity: } 99.8 \text { (99.6-99.9) }\end{array}$ \\
\hline $\begin{array}{l}\text { Kimer } \\
2012 \text { [27] }\end{array}$ & $\begin{array}{l}\text { Quality of systematic } \\
\text { Review } \\
\text { AMSTAR: 7/11 } \\
\text { GRADE Certainty of } \\
\text { Evidence } \\
\text { Very Low }\end{array}$ & $\begin{array}{l}\text { Systematic Review } \\
\text { Up to } 2012 \\
\mathrm{~N}=\text { eight RCTs, five } \\
\text { prospective cohorts }\end{array}$ & $\begin{array}{l}\text { RCTs conducted in France, Italy, Spain, } \\
\text { Japan, and USA in patients with } \\
\text { HCV-related cirrhosis or fibrosis and } \\
\text { treated with antiviral therapy } 1156 \\
\text { patients with therapy } \\
1074 \text { controls } \\
\text { Prospective cohorts: } \\
\text { Patients with HCV-related cirrhosis }\end{array}$ & $\begin{array}{l}\text { Intervention: } \\
\text { Antiviral therapy (PR, IFN, PEG-IFN) } \\
\text { Outcome: } \\
\text { RR, } 95 \% \text { CI of HCC development; } \\
\text { number needed to treat to prevent } 1 \\
\text { case of HCC }=1 / \text { risk difference } \\
\text { overall mortality } \\
\text { liver-related mortality } \\
\text { liver-related morbidity }\end{array}$ & $\begin{array}{l}\text { Risk of HCC among received } \\
\text { antiviral therapy vs. did not receive: } \\
\text { Absolute number of HCC: } 81 / 1156 \\
\text { vs. } 129 / 1174 \\
\text { RR }(95 \% \text { CI): } 0.53(0.34-0.81) \\
\text { SVR and non-SVR compared to no } \\
\text { therapy-RR }(95 \% \text { CI): } \\
\text { SVR: RR }=0.15(0.05-0.45) \\
\text { Non-SVR: RR }=0.57(0.37-0.85) \\
\text { Number needed to treat to prevent } \\
\text { one case of HCC: eight patients. }\end{array}$ \\
\hline $\begin{array}{l}\text { Simmons } \\
2015 \text { [28] }\end{array}$ & $\begin{array}{l}\text { Quality of systematic } \\
\text { Review } \\
\text { AMSTAR: } 8 / 11 \\
\text { GRADE Certainty of } \\
\text { Evidence } \\
\text { Very low to low }\end{array}$ & $\begin{array}{l}\text { Systematic Review } \\
\text { 1990-2014 } \\
\text { N = 31 studies: } \\
\text { General population: } 17 \\
\text { studies; } \\
\text { Cirrhotic: nine studies; } \\
\text { HIV co-infected: five } \\
\text { studies }\end{array}$ & $\begin{array}{l}\text { Adults ( }>18 \text { years old) chronically } \\
\text { infected with HCV of any genotype } \\
\text { treated with any antiviral regimen } \\
\text { stratified into } 3 \text { groups: } \\
1-\quad \text { patients at any disease stage } \\
2-\quad \text { cirrhotic patients } \\
3-\quad \text { HIV/HCV co-infected } \\
\text { Total: } 33,336 \text { participants } \\
\text { General population: } 28,398 \\
\text { Cirrhotic: } 2604 \\
\text { HIV co-infected: } 2358\end{array}$ & $\begin{array}{l}\text { Intervention: } \\
\text { PR; IFN; PEG-IFN; IFN-beta } \\
\text { Outcome: } \\
\text { all-cause mortality; } \\
\text { pooled adjusted HR }(95 \% \mathrm{CI}) \text {; pooled } \\
\text { estimates for the 5-year mortality }\end{array}$ & $\begin{array}{l}\text { Mortality of achieved SVR vs. } \\
\text { non-SVR, aHR ( } 95 \% \text { CI): } \\
\text { General population: } 0.50(0.37-0.67) \\
\text { Cirrhotic group: } 0.26 \text { (0.18-0.74) } \\
\text { HIV co-infected group: } 0.21 \\
\text { (0.10-0.45) } \\
\text { Pooled 5-year mortality rates for SVR } \\
\text { vs. non-SVR, IR ( } 95 \% \text { CI): } \\
\text { General population: } 1.98 \text { (1.00-3.45) } \\
\text { vs. } 7.75 \text { (5.86-10.98) } \\
\text { Cirrhotic group: } 4.90(3.45-7.28) \text { vs. } \\
\text { 15.88 (11.44-21.80) } \\
\text { Co-infected group: } 1.49(0.50-2.96) \\
\text { vs. } 11.44 \text { (6.33-19.3) }\end{array}$ \\
\hline
\end{tabular}


Table 1. Cont.

\begin{tabular}{|c|c|c|c|c|c|}
\hline Study & $\begin{array}{l}\text { Quality of Systematic } \\
\text { Review/GRADE } \\
\text { Certainty of Evidence }\end{array}$ & Design & Population & Intervention/Outcomes & Results \\
\hline $\begin{array}{l}\text { Public Health Agency } \\
\text { of Canada, Canadian } \\
\text { Task Force on } \\
\text { Preventative Health } \\
\text { Care } \\
2016 \text { [29] }\end{array}$ & $\begin{array}{l}\text { Quality of systematic } \\
\text { Review } \\
\text { AMSTAR: } 11 / 11 \\
\text { GRADE Certainty of } \\
\text { Evidence } \\
\text { Very low to moderate }\end{array}$ & $\begin{array}{l}\text { Systematic Review } \\
\text { Up to November } 2015 \\
\mathrm{~N}=\text { Benefits of treatment: } \\
11 \text { studies; } \\
\text { Harms of treatment: } 7\end{array}$ & $\begin{array}{l}\text { Treatment-naïve nonpregnant HIV /HBV } \\
\text { negative adults } \\
\text { Wide range of fibrosis scores }+80 \% \\
\text { noncirrhotic } \\
\text { RCTs }(\mathrm{n}=7) \\
6 / 7 \text { RCTs all patients were Genotype } 1 \\
2431 \text { participants ranged from } 121 \text { to } 499 \\
\text { participants in a study. } \\
\text { Recruitment sites included: United } \\
\text { States, Australia, Austria, Belgium, } \\
\text { Canada, Denmark, France, Germany, } \\
\text { New Zealand, Norway, Poland, Russia, } \\
\text { Spain, Japan, Italy, Mexico, Puerto Rico, } \\
\text { Romania, Ukraine, United Kingdom, } \\
\text { Sweden, the Netherlands, Bulgaria, } \\
\text { Portugal, Slovakia, China, and the } \\
\text { Republic of Korea. }\end{array}$ & $\begin{array}{l}\text { Intervention: } \\
\text { DAA-based vs. PR regimens. } \\
\text { DDA therapies included those that } \\
\text { were approved at the time of the } \\
\text { study and those anticipated to be } \\
\text { approved by February } 2016 \text { for all } \\
\text { HCV genotypes. } \\
\text { Outcomes: } \\
\text { All-cause mortality; } \\
\text { hepatic mortality; } \\
\text { hepatic decompensation; } \\
\text { hepatocellular carcinoma; } \\
\text { need for liver transplantation. }\end{array}$ & $\begin{array}{l}\text { Hepatic mortality: } 60 \text { fewer } / 1000 \\
\text { (95\% CI 59-62) } \\
\text { Hepatocellular carcinoma: } 18 \\
\text { fewer/1000 (17-19) } \\
\text { Decompensated cirrhosis: } 46 \\
\text { fewer/1000 (46-47) } \\
\text { Need for liver transplantation: } 4 \\
\text { fewer/1000 (4-6) } \\
\text { In cirrhotic individuals DAA-based } \\
\text { regimens compared to PR resulted in } \\
30 \text { fewer/1000 people affected by } \\
\text { hepatic mortality. }\end{array}$ \\
\hline $\begin{array}{l}\text { Yehia } \\
2014 \text { [30] }\end{array}$ & $\begin{array}{l}\text { Quality of systematic } \\
\text { Review } \\
\text { AMSTAR: } 3 / 11 \\
\text { Data quality not } \\
\text { formally assessed }\end{array}$ & $\begin{array}{l}\text { Systematic Review } \\
2003-2013 \\
N=10 \text { studies }\end{array}$ & $\begin{array}{l}\text { Only studies from the US that collected } \\
\text { data after } 2000 \text { were included. } \\
\text { Studies of the general population } \\
\text { excluded those with only a single study } \\
\text { site, exclusively focused on specific } \\
\text { populations (e.g., only immigrants, } \\
\text { injection drug users, those with } \\
\text { HIV/HCV co-infection) } \\
\text { Study subjects for each question } \\
\text { Chronic infection: } 15,079 \\
\text { Diagnosed/Aware: } 203 \\
\text { Access to Care: } 101 \\
\text { HCV RNA confirmed: } 8810 \\
\text { Liver biopsy: } 180,703 \\
\text { Prescribed HCV treatment: } 46,452 \\
\text { Achieved SVR: } 18,105\end{array}$ & $\begin{array}{l}\text { Examined data addressing seven key } \\
\text { steps along the HCV care and } \\
\text { treatment cascade }\end{array}$ & $\begin{array}{l}\text { Care/Treatment cascade: } \\
100 \% \text { Chronic HCV infected } \\
(3,500,000) \\
50 \% \text { Diagnosed and aware } \\
43 \% \text { Access to outpatient care } \\
27 \% \text { HCV RNA confirmed } \\
17 \% \text { Underwent liver biopsy } \\
16 \% \text { Prescribed HCV treatment } \\
9 \% \text { Achieved SVR }\end{array}$ \\
\hline
\end{tabular}

AMSTAR: A MeaSurement Tool to Assess systematic Reviews [22]; aHR: adjusted hazard ratio; CI: confidence interval; CIA: chemiluminescence immunoassay; DAA: direct acting antiviral; EIA: enzyme immunoassay; GRADE: the grading of recommendation assessment, development and evaluation; HCC: hepatocellular carcinoma; HCV: hepatitis C virus; HIV: human immunodeficiency virus; HR: hazard ratio; IFN: interferon; IR: incidence rate; LR: likelihood ratio; NAT: nucleic acid test; OR: odds ratio; PEG-IFN: pegylated interferon; PR pegylated-interferon-ribavirin; RBV: ribavirin; RCT: randomized controlled trial; RIBA: recombinant immunoblot assay; RNA: ribonucleic acid; RR: risk ratio; SVR: sustained virological response; US: United States; WHO: World Health Organization. 


\subsection{Impact of Therapy on Long-Term Outcomes}

Interferon free DAAs are the recommended therapy for all HCV genotypes in the EU/EEA [8]. These regimens are well tolerated and cure $>95 \%$ of cases based on achieving sustained virologic response (SVR0, which is considered to be a reliable surrogate outcome for HCV cure) [7,8]. Within the search dates we did not identify any studies that examined the impact of DAA therapies on long-term HCV liver related outcomes or mortality, as these agents only became available in 2013. Three SRs that assessed the impact of older interferon (IFN) based HCV treatment on preventing liver related sequelae and all-cause mortality were included [27-29]. These three SRs included studies from Europe, North America, Australia, and Asia, and found that IFN-based HCV therapy significantly decreased rates of hepatocellular carcinoma (HCC), hepatic decompensation, and all-cause mortality in those on HCV treatment, and particularly in those who achieved SVR [27-29]. In a meta-analysis by Kimer et al., the risk of HCC was lower in those on antiviral HCV therapy (IFN or PEG-IFN alone or with ribavirin) compared to placebo or no intervention ( $R R=0.53,95 \%$ CI $0.34-0.81$ ). This effect was much more pronounced among virological responders compared to nonresponders [27]. In the SR by Simmons et al., the adjusted hazard ratio (aHR) of all-cause mortality rate was lower in patients on treatment for chronic HCV after a median follow-up time of 5.4 years [28]. In those achieving SVR, compared with non-SVR, the aHR was 0.50 (95\% CI: 0.37-0.67) in the general population, and 0.26 (95\% CI: 0.18-0.37) in the cirrhotic group [28]. Finally, in the SR conducted by the Public Health Agency of Canada (PHAC), a reduction in hepatic mortality (60 fewer/1000, 95\% CI: 59-62), HCC (18 fewer/1000, 95\% CI: 17-19), hepatic decompensation or decompensated cirrhosis (46 fewer /1000, 95\% CI: 46-47), and need for liver transplantation (4 fewer/1000, 95\% CI: 4-5) among those treated with DAA to PEG-IFN was found [29]. The GRADE certainty of the evidence of the data in these three systematic reviews was very low to moderate (GRADE Tables S3-S5).

\subsection{The HCV Care Continuum and Pathway}

In a SR of studies of the HCV care continuum in the pre-DAA period among in the general population in the US from 2003-2013, only 50\% of HCV cases were diagnosed and aware of their infection, $27 \%$ had HCV RNA confirmatory testing, 16\% were prescribed HCV therapy, and 9\% achieved SVR [30]. The results of this study were not stratified by risk group nor did they report on the barriers to uptake of the steps along the care cascade. A modeling study in Europe published after the search timeframe also demonstrated a weak HCV care continuum in 2015, consistent with the US SR by Yehia [2]. They found that in Europe in 2015, only 36\% of HCV infected persons have been screened and, of those diagnosed, only $12.7 \%$ and $11.3 \%$ had been treated and cured, respectively [2]. They found that, to achieve WHO elimination targets, expansion of screening programs in the EU/EAA would be needed along with unrestricted access to treatment for all found to be infected.

\subsection{Resource Use, Costs and Cost-Effectiveness}

Screening for HCV in those treated with DAAs is cost-effective even at higher 2015 costs. A UK study evaluated the cost-effectiveness of screening and treating pregnant women attending antenatal clinics [44]. The incremental cost effectiveness ratio (ICER) for screening and treatment (PR) compared with no screening and no treatment was $£ 2400$ (€2745) per QALY gained. For screening and treating with DAAs compared with no screening and no treatment, the ICER was still cost-effective at $£ 9139$ $(€ 10,455) / Q A L Y$ gained. A Canadian study evaluated the cost-effectiveness of screening for HCV in different age groups and then treating with DAAs in the Canadian population where the HCV seroprevalence ranged from 0.3 to $0.8 \%$ [32]. The ICER for IFN-free DAAs vs. older therapies ranged from CAN $\$ 34,359$ (€21,977) to CAN\$44,034 $(€ 28,166)$ per QALY gained [32]. In the US, Rein et al. found that screening followed by DAA therapy was moderately cost-effective with ICERs ranging from US $\$ 47,237(€ 40,665)$ to US\$72,169 $(€ 62,128)$ per QALY gained [36]. 
The Drummond Criteria [24]: (i) Was a well-defined question posed in answerable form? (ii) Was a comprehensive description of the competing alternatives given (i.e., can you tell who did what to whom, where, and how often)? (iii) Was the effectiveness of the program or services established? (iv) Were all the important and relevant costs and consequences for each alternative identified? (v) Were costs and consequences measured accurately in appropriate physical units (e.g., hours of nursing time, number of physician visits, lost working days, and gained life years)? (vi) Were the cost and consequences valued credibly? (vii) Were costs and consequences adjusted for differential timing? (viii) Was an incremental analysis of costs and consequences of alternatives performed? (ix) Was allowance made for uncertainty in the estimates of costs and consequences? (x) Did the presentation and discussion of study results include all issues of concern to users?

Non-pan-genotypic DAA therapies have also been found to be moderately cost-effective, however they had a large budget impact at the 2015 cost of treatment [31]. Deuffic-Burban found that DAAs were moderately cost-effective for genotypes 1 and 4 regardless of fibrosis stage, ranging from $€ 40,000$ to $€ 88,000$ per quality-adjusted life year (QALY) gained (Table 2). IFN-based regimens were estimated to be more cost-effective for genotypes 2 or 3 at $€ 21,300$ to $€ 19,400$ per QALY gained regardless of fibrosis stage [31]. DAAs were found to be moderately cost-effective for genotype $1 \& 4$ at a median threshold of $€ 24,000 /$ QALY gained and maximum upper limit of $€ 80,000 /$ QALY gained however, introducing these regimens on a wide scale would have a substantial budget impact of $€ 3.5-7.2$ billion on the French health care system [31,45]. Several US studies have evaluated the cost-effectiveness of DAA therapies compared to older PEG-INF-RBV therapies and found that DAA therapies were moderately cost-effective at a willingness-to-pay threshold of $\$ 50,000$ US $(€ 39,210)$, but varied significantly by HCV genotype, presence of liver fibrosis, and treatment history [33-38]. In the US, DAAs were moderately cost-effective for genotypes $1 \& 4$ whereas IFN-RBV was more cost-effective for genotypes $2 \& 3$. DAAs were more cost-effective in the presence of cirrhosis and treatment naïve patients. Providing DAAs to all eligible HCV patients would also have a huge budget impact, costing an additional US\$65 (€56) billion over a 5-year period, whereas the resulting cost-offsets were estimated at only US\$16 (€14) billion [34]. 
Table 2. Included studies on the cost, resource use, and cost-effectiveness of HCV screening and direct acting antiviral therapies.

\begin{tabular}{|c|c|c|c|c|c|}
\hline Study & $\begin{array}{l}\text { Quality/Certainty of } \\
\text { Economic Evidence }\end{array}$ & Design/Population & Intervention(s) & $\begin{array}{l}\text { Cost-Effectiveness } \\
\text { (ICER or INB) }\end{array}$ & Resource Requirements \\
\hline \multicolumn{6}{|c|}{ Cost-effectiveness of HCV Screening and DAA therapy } \\
\hline $\begin{array}{l}\text { Brett-Major } \\
2016[41]\end{array}$ & $\begin{array}{l}\text { Certainty of evidence: } \\
\text { moderate } \\
\text { Allowance was made for } \\
\text { uncertainty in the estimates of } \\
\text { costs, HCV rates, and ranges } \\
\text { were provided. Threshold } \\
\text { sensitivity analysis undertaken. } \\
\text { PSA not performed. } \\
\text { Justification for choice of ranges } \\
\text { was provided for all parameters. } \\
\text { Cost offsets (and net savings) } \\
\text { rather than cost-effectiveness } \\
\text { was reported }\end{array}$ & $\begin{array}{l}\text { Design: } \\
\text { Decision-analytic costing model; } \\
\text { results reported in US dollars } \\
\text { Population: } \\
\text { Applicants to US military service } \\
\text { HCV prevalence } 0.48-0.98 / 1000\end{array}$ & $\begin{array}{ll}1- & \text { Enzyme immunoassay } \\
\text { (EIA) screening } & \\
\text { 2- } & \text { EIA + nucleic acid testing } \\
\text { (NAT) screening } \\
\text { 3- } & \text { no screening } \\
\text { Treatment with SOF based } \\
\text { regimens }\end{array}$ & $\begin{array}{l}\text { Not applicable } \\
\text { (Costing study) }\end{array}$ & $\begin{array}{l}\text { High costs. } \\
\text { With no screening, the cost to the } \\
\text { Department of Defence of treating the } \\
\text { estimated } 93 \text { cases of chronic HCV cases } \\
\text { from a single year's accession cohort was } \\
\$ 9.3 \text { million }[67,293,134] \text {. } \\
\text { Screening with the HCV antibody test } \\
\text { followed by the nucleic acid test for } \\
\text { confirmation yielded a net annual savings } \\
\text { and a } \$ 3.1 \text { million dollar }[\text { [ani,431,044] } \\
\text { advantage over not screening. }\end{array}$ \\
\hline $\begin{array}{l}\mathrm{He} \\
2016[42]\end{array}$ & $\begin{array}{l}\text { Certainty of evidence: } \\
\text { moderate } \\
\text { Allowance was made for } \\
\text { uncertainty in the estimates of } \\
\text { costs and consequences, and } \\
\text { ranges were provided. } \\
\text { PSA not performed. } \\
\text { Justification for choice of ranges } \\
\text { was not trovided for all } \\
\text { parameters. } \\
\text { Cost-effectiveness results were } \\
\text { sensitive to the time horizon. }\end{array}$ & $\begin{array}{l}\text { Design: } \\
\text { Dynamic microsimulation model } \\
\text { of transmission/progression of } \\
\text { HCV, and cost-effectiveness and } \\
\text { budget impact analysis; results } \\
\text { reported in US dollars } \\
\text { Population: } \\
\text { Population in US prisons } \\
\text { HCV prevalence 25\% and 50\% } \\
\text { undiagnosed }\end{array}$ & $\begin{array}{l}\text { Three strategies: } \\
\text { 1- } \quad \text { risk-based screening } \\
2-\quad \text { universal opt-out screening } \\
3-\quad \text { no screening } \\
\text { Treatment with SOF based } \\
\text { regimens }\end{array}$ & $\begin{array}{l}\text { ICER (\$/QALY gained): } \\
1 \text { year risk-based vs. no screening: } \$ 19,635[\in 15,552] \\
\mathbf{1} \text { year universal vs. no screening: } \\
\$ 20,571[\text { [E16,293] } \\
5 \text { year universal vs. no screening: } \\
\$ 24,046[\epsilon 19,046] \\
10 \text { year universal vs. no screening: } \$ 29,234[\in 23,155]\end{array}$ & 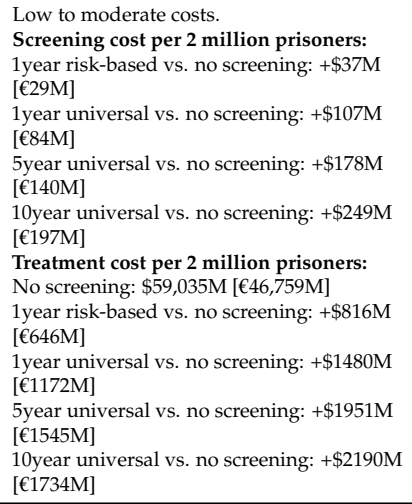 \\
\hline
\end{tabular}


Table 2. Cont.

\begin{tabular}{|c|c|c|c|c|c|}
\hline Study & $\begin{array}{l}\text { Quality/Certainty of } \\
\text { Economic Evidence }\end{array}$ & Design/Population & Intervention(s) & $\begin{array}{l}\text { Cost-Effectiveness } \\
\text { (ICER or INB) }\end{array}$ & Resource Requirements \\
\hline \multicolumn{6}{|c|}{ Cost-effectiveness of HCV Screening and DAA therapy } \\
\hline $\begin{array}{l}\text { Orkin } \\
2016[43]\end{array}$ & $\begin{array}{l}\text { Certainty of evidence: low } \\
\text { Allowance was not made for } \\
\text { uncertainty in the estimates of } \\
\text { costs and consequences. No } \\
\text { source for unit prices (costs) } \\
\text { was given. } \\
\text { PSA not performed. } \\
\text { Justification for choice of ranges } \\
\text { was not provided for all } \\
\text { parameters. } \\
\text { Cost-effectiveness results were } \\
\text { not reported. }\end{array}$ & $\begin{array}{l}\text { Design: } \\
\text { Prospective } 1 \text { week-long } \\
\text { snapshot observational study } \\
\text { with hassumed costs for testing } \\
\text { and treating; results reported in } \\
\text { British pounds } \\
\text { Population: } \\
\text { People visiting emergency } \\
\text { departments in the UK } \\
\text { HCV prevalence } 1.84 \%\end{array}$ & $\begin{array}{l}\text { One strategy: } \\
\text { Routine combined } \mathrm{HIV}, \mathrm{HCV} \text {, and } \\
\text { HBV testing }\end{array}$ & Not applicable & $\begin{array}{l}\text { Low to moderate costs. } \\
\text { Assuming the cost per diagnosis is } € 7 \text { [€8], } \\
\text { the cost } \\
\text { per new case detected would be } £ 988 \text { [ [€1109] } \\
\text { for HCV, } € 1351 \text { [ }[1517] \text { for } \mathrm{HBV} \text {. and } £ 2478 \\
\text { [€2783] for HIV. }\end{array}$ \\
\hline $\begin{array}{l}\text { Rein } \\
2015 \text { [36] }\end{array}$ & $\begin{array}{l}\text { Certainty of evidence: high } \\
\text { Allowanne was made for } \\
\text { uncertainty in the estimates of } \\
\text { costs and consequences, and } \\
\text { ranges were provided. } \\
\text { PSA was performed. } \\
\text { Justification for choice of ranges } \\
\text { was provided for all parameters. } \\
\text { Cost-effectiveness results were } \\
\text { sensitive to treatment cost, SVR } \\
\text { probability, QALY post SVR, } \\
\text { fibrosis rate }\end{array}$ & $\begin{array}{l}\text { Design: } \\
\text { Monte Carlo simulation model; } \\
\text { results presented in US dollars. } \\
\text { Population: } \\
\text { General population aged } \geq 20, \\
\text { and patients with chronic HCV } \\
\text { genotype } 1,2,3, \text { and } 4 \text { in US } \\
\text { HCV prevalence rate: varies by } \\
\text { birth decade, race, and sex } \\
\text { Heavy alcoholics } 0.089 \\
\text { HIV }+0.02\end{array}$ & $\begin{array}{ll}\text { Screening followed by treatment } \\
\text { Five strategies: } \\
\begin{array}{ll} & \\
1- & \text { PR } \\
2- & \text { PI+PR } \\
3- & \text { SOF+PR } \\
4- & \text { SOF+SIM } \\
5- & \text { SOF+RBV }\end{array}\end{array}$ & 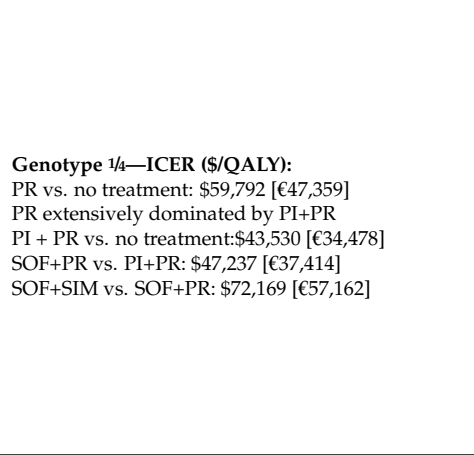 & 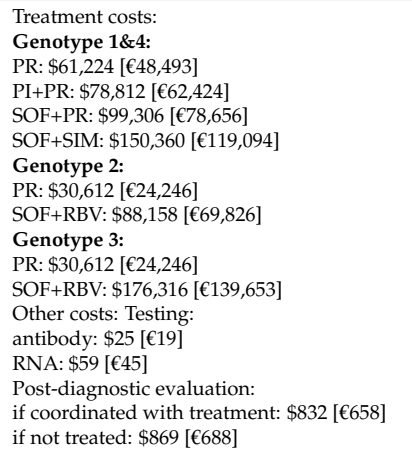 \\
\hline
\end{tabular}


Table 2. Cont.

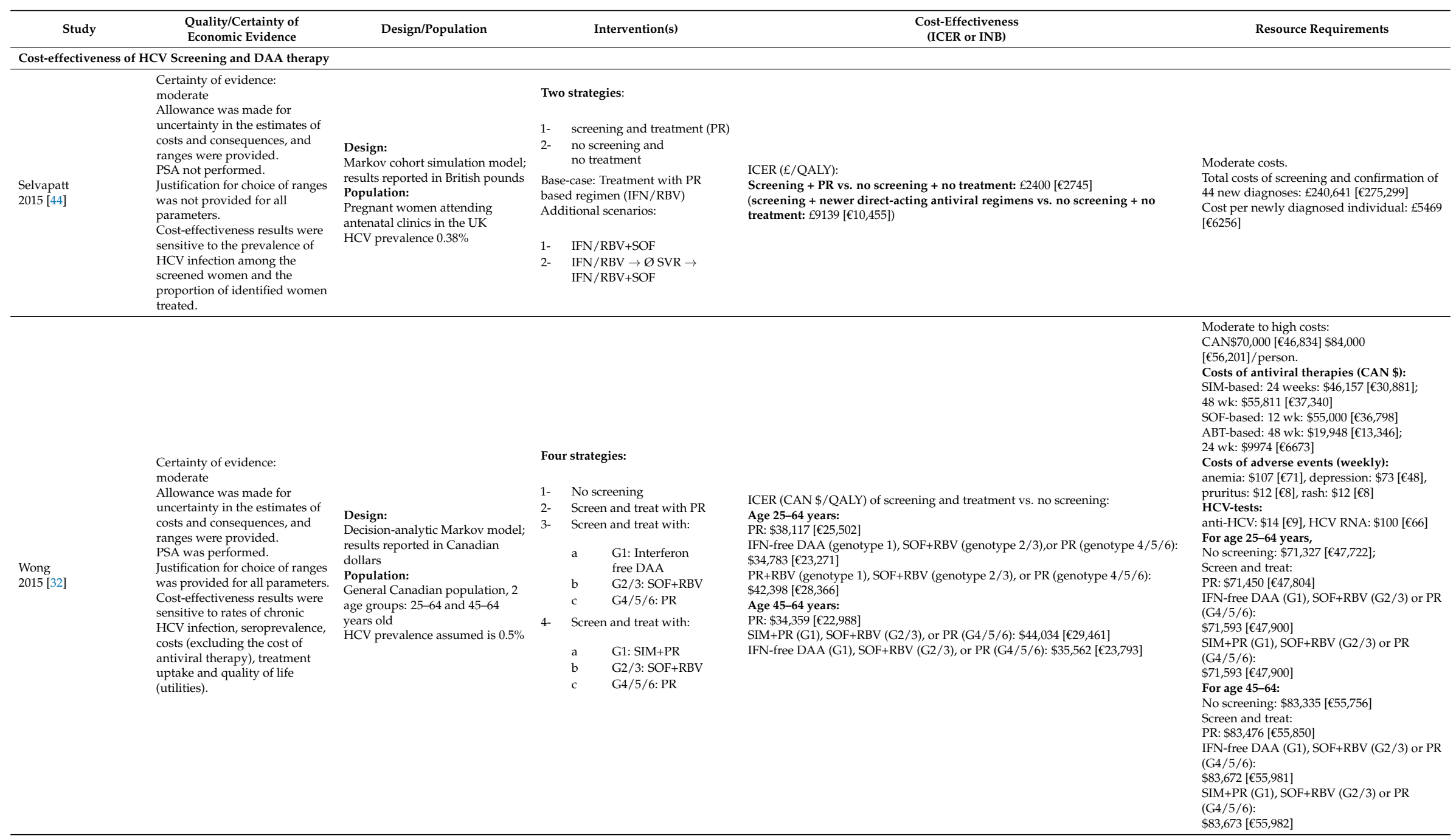


Table 2. Cont.

\begin{tabular}{|c|c|c|c|c|c|}
\hline Study & $\begin{array}{l}\text { Quality/Certainty of } \\
\text { Economic Evidence }\end{array}$ & Design/Population & Intervention(s) & $\begin{array}{l}\text { Cost-Effectiveness } \\
\text { (ICER or INB) }\end{array}$ & Resource Requirements \\
\hline \multicolumn{6}{|c|}{ Cost-effectiveness of HCV Screening and DAA therapy } \\
\hline $\begin{array}{l}\text { Chhatwal } \\
2015 \text { [34] }\end{array}$ & $\begin{array}{l}\text { Certainty of evidence: high } \\
\text { Allowance was made for } \\
\text { uncertainty in the estimates of } \\
\text { costs and consequences, and } \\
\text { ranges were provided. } \\
\text { PSA was performed. } \\
\text { Justification for choice of ranges } \\
\text { was provided for all parameters. } \\
\text { Cost-effectiveness results were } \\
\text { most sensitive to quality of life } \\
\text { after successful treatment, cost } \\
\text { of SOF, drug efficacy } \\
\end{array}$ & $\begin{array}{l}\text { Design: } \\
\text { Decision-analytic Markov model; } \\
\text { results reported in US dollars } \\
\text { Population: } \\
\text { Treatment naive and } \\
\text { treatment-experienced HCV } \\
\text { population in US }\end{array}$ & $\begin{array}{ll}\text { Two strategies: } \\
\begin{array}{ll}1- & \text { SOF-LDV } \\
2- & \text { IFN-based therapy }\end{array}\end{array}$ & $\begin{array}{l}\text { SOF-LDV vs. IFN-based therapy-ICER }(\$ / Q A L Y) \text { : } \\
\text { Treatment naive patients: } \\
\text { No cirrhosis: } \$ 61,517[648,725 .] \\
\text { Cirrhosis: } \$ 20,677 \text { [ }[16,374] \\
\text { Treatment experienced patients: } \\
\text { No cirrhosis: } \$ 69,707[655,212] \\
\text { Cirrhosis: } \$ 92,302[673,109]\end{array}$ & 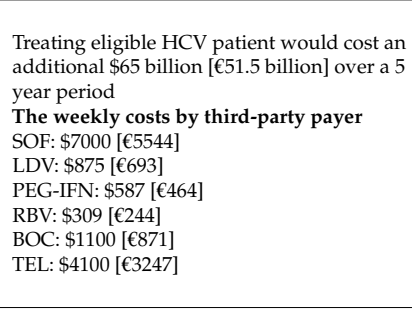 \\
\hline $\begin{array}{l}\text { Deuffic-Burban } \\
2016[31]^{*}\end{array}$ & $\begin{array}{l}\text { Certainty of evidence: } \\
\text { moderate } \\
\text { Allowance was made for } \\
\text { uncertainty in the estimates of } \\
\text { costs and consequences, and } \\
\text { ranges were provided. } \\
\text { PSA not performed. } \\
\text { Limited justification for choice } \\
\text { of ranges. } \\
\text { Cost-effectiveness results were } \\
\text { sensitive to the price of new } \\
\text { DAAs particularly for treating } \\
\text { genotype } 1\end{array}$ & $\begin{array}{l}\text { Design: } \\
\text { Decision-analytic Markov model; } \\
\text { results reported in Euros } \\
\text { Population: } \\
\text { Patients with chronic HCV aged } \\
\geq 18 \text {, aware of their infection, in } \\
\text { fibrosis stage F0-F4 or } \\
\text { decompensated cirrhosis, treated } \\
\text { in France. } \\
\text { HCV prevalence }\end{array}$ & $\begin{array}{l}\text { 1- } \quad \text { TVR/BOC-based triple } \\
\text { therapy for genotype } 1 \text { and } \\
\text { dual therapy with PR for } \\
\text { genotypes other than } 1 \text { (at F2) } \\
\text { 2- } \quad \text { SOF/SIM+PR } \\
\text { 3- } \quad \text { IFN-free DAAs with or } \\
\text { without RBV } \\
\text { Strategies } 2 \text { \& } 3 \text { evaluated starting } \\
\text { treatment at } \geq \text { F3, } \geq \text { F2 or } \\
\text { regardless of fibrosis }\end{array}$ & $\begin{array}{l}\text { Genotype } 1: \\
\text { IFN-free was a cost-effective vs. IFN-based: } \\
\text { ICER: } € 40,400 \text { to } € 88,300 / \text { QALY } \\
\text { QAL/person: } 12.59 \text { vs. } 12.11 \text { for IFN-based therapy } \\
\text { Genotypes } 2 \text { or } 3: \\
\text { IFN-based was the most cost-effective: } \\
\text { ICER } € 21,300 / \text { /QALY for genotype } 2 \\
\text { ICER: } € 19,400 / Q A L Y \text { for genotype } 3 \\
\text { Genotype } 4: \\
\text { IFN-free regimens was cost-effective: } \\
\text { ICER: } € 23,000 \text { to } € 58,200 / Q A L Y\end{array}$ & $\begin{array}{l}\text { Moderate to high resource } \\
\text { Treating all CHC-screened patients over } 5 \\
\text { years would cost: } € 3.5-7.2 \text { billion } \\
\text { Cost of treatment/week: } \\
\text { SOF: } € 3417 \\
\text { OBV /PTV-r: } € 3259 \\
\text { DCV: } € 2125 \\
\text { IIM: } € 1750 \\
\text { TEL: } € 1042 \\
\text { LDV: } € 417 \\
\text { BOC: } € 378 \\
\text { DAV: } € 284 \\
\text { PEG-IFN: } € 158 \\
\text { RBV: } € 55 \\
\text { Costs related to adverse events (cost per } \\
\text { event): } \\
\text { Severe anaemia: } € 2564 \\
\text { Severe depression: }: 1619 \\
\text { Severe rashh } € 2942 \\
\text { Moderate anaemia: } € 4200\end{array}$ \\
\hline
\end{tabular}


Table 2. Cont.

\begin{tabular}{|c|c|c|c|c|c|}
\hline Study & $\begin{array}{l}\text { Quality/Certainty of } \\
\text { Economic Evidence }\end{array}$ & Design/Population & Intervention(s) & $\begin{array}{l}\text { Cost-Effectiveness } \\
\text { (ICER or INB) }\end{array}$ & Resource Requirements \\
\hline \multicolumn{6}{|c|}{ Cost-effectiveness of HCV Screening and DAA therapy } \\
\hline $\begin{array}{l}\text { Hagan } \\
2014[37]\end{array}$ & $\begin{array}{l}\text { Certainty of evidence: } \\
\text { moderate } \\
\text { Allowance was made for } \\
\text { uncertainty in the estimates of } \\
\text { costs and consequences, and } \\
\text { ranges were provided. } \\
\text { PSA not performed. } \\
\text { Justification for choice of ranges } \\
\text { was provided for all parameters. } \\
\text { Cost-effectiveness results were } \\
\text { sensitive to SVR rates }\end{array}$ & $\begin{array}{l}\text { Design: } \\
\text { Decision-analytic Markov model; } \\
\text { results reported in US dollars } \\
\text { Population: } \\
\text { Chronic HCV genotype 1, in } 50 \\
\text { years old in US } \\
\text { HCV prevalence } 1.6 \%\end{array}$ & $\begin{array}{l}\text { Two strategies: } \\
\begin{array}{ll}1- & \text { SOF } / \mathrm{RBV} \\
2- & \mathrm{SOF} / \mathrm{SIM}\end{array}\end{array}$ & $\begin{array}{l}\text { SOF-SIM dominated SOF-RBV: yielded lower costs and more QALYs } \\
\text { SOF-SIM: } \$ 165,336 \text { [€133,108] } \\
\text { and } 14.69 \text { QALYs } \\
\text { SOF-RBV: } \$ 243,586[€ 196,106] \\
\text { and } 14.45 \text { QALYs }\end{array}$ & $\begin{array}{l}\text { Costs of drugs per course: } \\
\text { 24-weeks SOF/RBV: } \$ 169,000 \\
\text { 12-weeks SOF/SIM: } \$ 150,000 \\
\text { Treatment-associated medical care: } \\
\text { SOF/RBV: } \$ 210100(1890-2310) \\
\text { [€1690 (€1521-€1859)] } \\
\text { SOF/SIM: } \$ 1160(1044-1276) \\
\text { [€933( } 6840-€ 1027)]\end{array}$ \\
\hline $\begin{array}{l}\text { Leidner } \\
2015[40]\end{array}$ & $\begin{array}{l}\text { Certainty of evidence: } \\
\text { moderate } \\
\text { Allowance was made for } \\
\text { uncertainty in the estimates of } \\
\text { costs and consequences, and } \\
\text { ranges were provided. } \\
\text { PSA not performed. } \\
\text { Justification for choice of ranges } \\
\text { was provided for all parameters. } \\
\text { Cost-effectiveness results were } \\
\text { sensitive to post-treatment } \\
\text { quality of life (utilities) and } \\
\text { treatment costs. }\end{array}$ & $\begin{array}{l}\text { Design: } \\
\text { Decision-analytic Markov model; } \\
\text { results reported in US dollars } \\
\text { Population: } \\
\text { 55-year old patient in US with } \\
\text { genotype } 1 \mathrm{HCV} \text { infection }\end{array}$ & $\begin{array}{l}\text { Two strategies: } \\
\begin{aligned} & \\
& 1- \text { treatment at fibrosis stages F3 } \\
& \text { and F4 } \\
& 2-\quad \begin{array}{l}\text { treatment strategies at earlier } \\
\text { stages of liver disease } \\
\text { (fibrosis stages } \mathrm{F} 2, \mathrm{~F} 1, \text { or F0). }\end{array}\end{aligned}\end{array}$ & 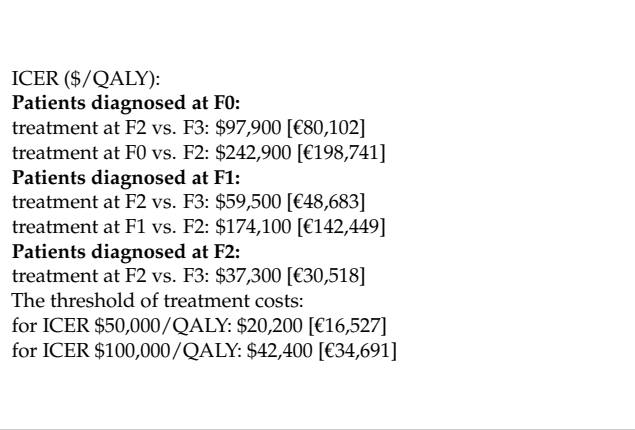 & 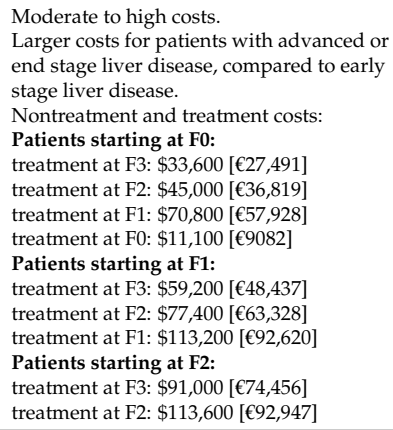 \\
\hline
\end{tabular}


Table 2. Cont.

\begin{tabular}{|c|c|c|c|c|c|}
\hline Study & $\begin{array}{l}\text { Quality/Certainty of } \\
\text { Economic Evidence }\end{array}$ & Design/Population & Intervention(s) & $\begin{array}{l}\text { Cost-Effectiveness } \\
\text { (ICER or INB) }\end{array}$ & Resource Requirements \\
\hline \multicolumn{6}{|c|}{ Cost-effectiveness of HCV Screening and DAA therapy } \\
\hline $\begin{array}{l}\text { Linas } \\
2015 \text { [39] }\end{array}$ & $\begin{array}{l}\text { Certainty of evidence: high } \\
\text { Allowance was made for } \\
\text { uncertainty in the estimates of } \\
\text { costs and consequences, and } \\
\text { ranges were provided. } \\
\text { PSA was performed. } \\
\text { Justification for choice of ranges } \\
\text { was provided for all parameters. } \\
\text { Cost-effectiveness results were } \\
\text { sensitive to cost of SOF }\end{array}$ & $\begin{array}{l}\text { Design: } \\
\text { Monte Carlo simulation. Results } \\
\text { reported in US dollars } \\
\text { Population: } \\
\text { Chronic HCV genotype } 2 \text { or } 3 \text { in } \\
\text { the US }\end{array}$ & $\begin{array}{ll}\text { Three strategies: } \\
\begin{array}{ll}1- & \text { SOF } \\
2- & \text { PR } \\
3- & \text { No therapy }\end{array}\end{array}$ & 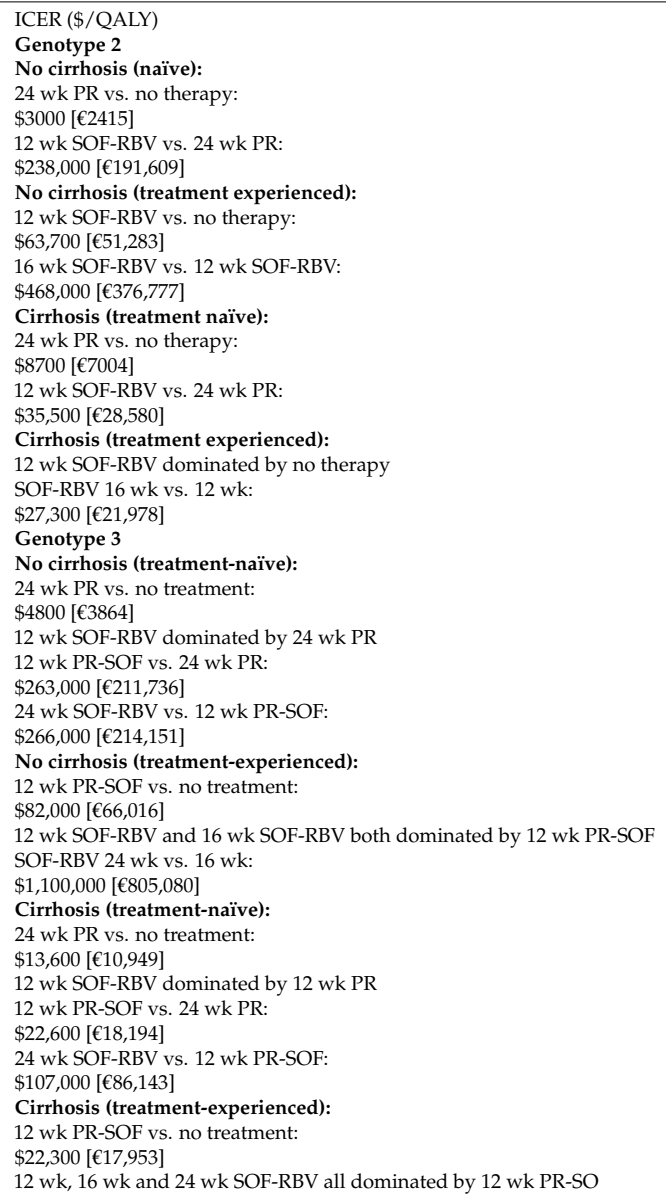 & 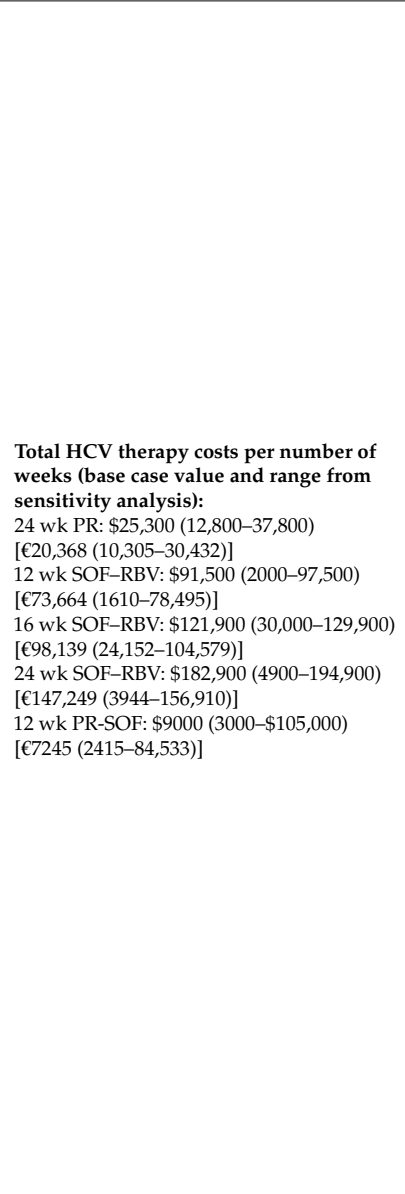 \\
\hline
\end{tabular}


Table 2. Cont

\begin{tabular}{|c|c|c|c|c|c|}
\hline Study & $\begin{array}{l}\text { Quality/Certainty of } \\
\text { Economic Evidence }\end{array}$ & Design/Population & Intervention(s) & $\begin{array}{l}\text { Cost-Effectiveness } \\
\text { (ICER or INB) }\end{array}$ & Resource Requirements \\
\hline \multicolumn{6}{|c|}{ Cost-effectiveness of HCV Screening and DAA therapy } \\
\hline $\begin{array}{l}\text { Najafzzadeh } \\
2015 \text { [33] }\end{array}$ & $\begin{array}{l}\text { Certainty of evidence: high } \\
\text { Allowance was made for } \\
\text { uncertainty in the estimates of } \\
\text { costs and consequences, and } \\
\text { ranges were provided. } \\
\text { PSA was performed. } \\
\text { Justification for choice of ranges } \\
\text { was provided for all parameters. } \\
\text { Cost-ffectiveness results were } \\
\text { sensitive to treatment cost }\end{array}$ & $\begin{array}{l}\text { Design: } \\
\text { Discrete event simulation } \\
\text { Population: } \\
\text { Treatment-naive patients infected } \\
\text { with chronic HCV genotype 1,2, } \\
\text { or } 3 \text { in the US. }\end{array}$ & 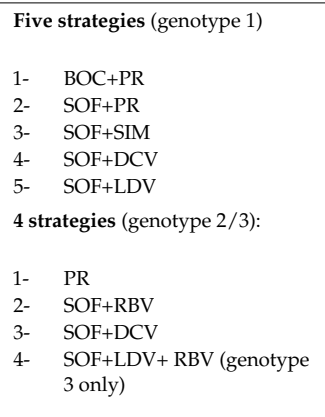 & 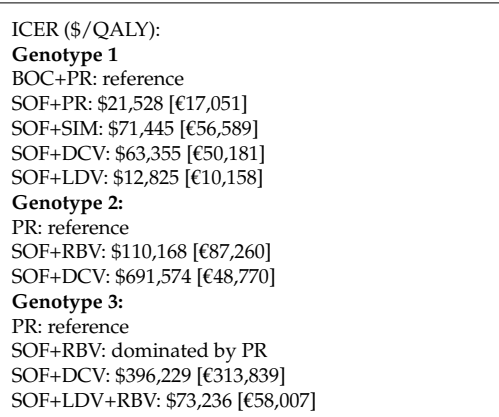 & 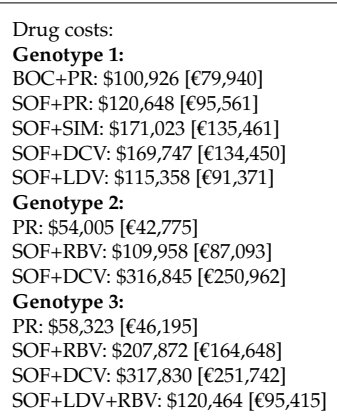 \\
\hline $\begin{array}{l}\text { Saab } \\
2014[38]\end{array}$ & $\begin{array}{l}\text { Certainty of evidence: } \\
\text { moderate } \\
\text { Allowance was made for } \\
\text { uncertainty in the estimates of } \\
\text { costs and consequences, and } \\
\text { ranges were provided. } \\
\text { PSA was performed. } \\
\text { Justification for choice of ranges } \\
\text { was not provided for all } \\
\text { parameters. } \\
\text { Cost-effectiveness results were } \\
\text { most sensitive to cirrhosis } \\
\text { prevalence and fibrosis rate, } \\
\text { recurrence rates in patients } \\
\text { achieving SVR. }\end{array}$ & $\begin{array}{l}\text { Design: } \\
\text { Decision-analytic Markov model; } \\
\text { results reported in US dollars } \\
\text { Population: } \\
\text { Patients with chronic HCV } \\
\text { genotype } 1 \text { in US }\end{array}$ & $\begin{array}{ll}1- & \mathrm{SOF}+\mathrm{PR} \\
2- & \mathrm{PR} \\
3- & \mathrm{BOC}+\mathrm{PR} \\
4- & \mathrm{TEL}+\mathrm{PR} \\
5- & \mathrm{SIM}+\mathrm{PR}\end{array}$ & 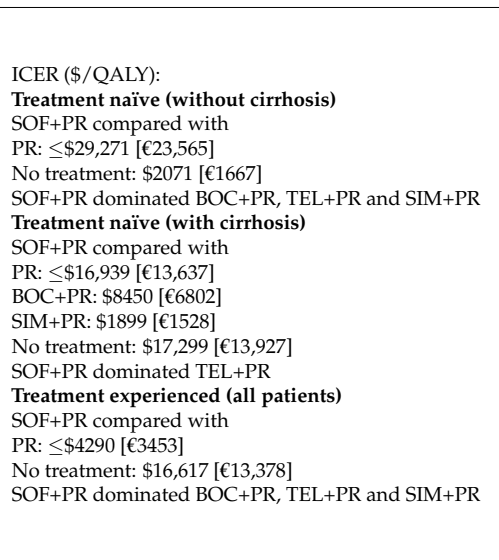 & 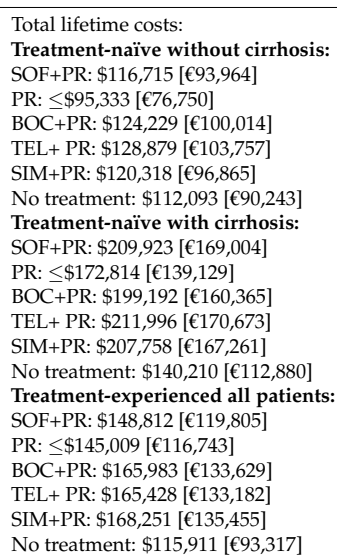 \\
\hline
\end{tabular}


Table 2. Cont

\begin{tabular}{|c|c|c|c|c|c|}
\hline Study & $\begin{array}{l}\text { Quality/Certainty of } \\
\text { Economic Evidence }\end{array}$ & Design/Population & Intervention(s) & $\begin{array}{l}\text { Cost-Effectiveness } \\
\text { (ICER or INB) }\end{array}$ & Resource Requirements \\
\hline \multicolumn{6}{|c|}{ Cost-effectiveness of HCV Screening and DAA therapy } \\
\hline $\begin{array}{l}\text { Younossi } \\
2015[35]\end{array}$ & $\begin{array}{l}\text { Certainty of evidence: } \\
\text { moderate } \\
\text { Allowanne was made for } \\
\text { uncertainty in the estimates of } \\
\text { costs and consequences, and } \\
\text { ranges were provided. } \\
\text { PSA was performed. } \\
\text { Justification for choice of ranges } \\
\text { was not provided for patient } \\
\text { distribution, regimen efficacy, } \\
\text { costs, or utilities. } \\
\text { Cost-effectiveness results were } \\
\text { robust across the limited ranges } \\
\text { tested. }\end{array}$ & $\begin{array}{l}\text { Design: } \\
\text { Decision-analytic Markov model; } \\
\text { results reported in US dollars } \\
\text { Population: } \\
\text { Patients with chronic HCV } \\
\text { genotype } 1 \text { in US. }\end{array}$ & $\begin{array}{l}\text { Six strategies: } \\
\begin{array}{ll}1- & \mathrm{LDV} / \mathrm{SOF} \\
2- & \mathrm{SOF}+\mathrm{PR} \\
3- & \mathrm{SIM}+\mathrm{PR} \\
4- & \mathrm{SOF}+\mathrm{SIM} \\
5- & \mathrm{SOF}+\mathrm{RBV} \\
6- & \mathrm{BOC}+\mathrm{PR}\end{array}\end{array}$ & $\begin{array}{l}\text { LDV/SOF (ICER): } \\
\text { Treatment-naive patients: } \\
\text { dominant over no treatment } \\
\text { dominant over SOF+PR (12/24 weeks) } \\
\text { less expensive and less effective than SOF+SIM } \\
\text { dominant over SOF }+ \text { RBV } \\
\text { dominant over BOC+PR } \\
\text { Results similar for patients with and without cirrhosis; and for treatment } \\
\text { experienced patients with PR or Protease inhibitor (PI) + RBV }\end{array}$ & 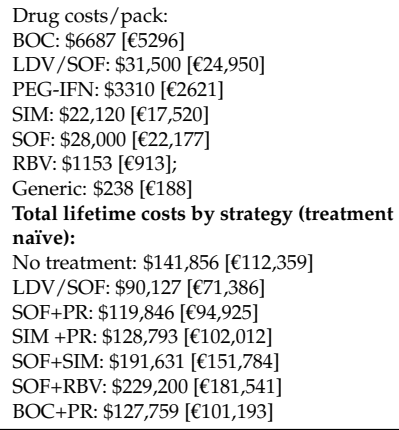 \\
\hline
\end{tabular}




\section{Discussion}

The data in this review supports the effectiveness and cost-effectiveness of HCV screening in populations at risk for $\mathrm{HCV}$ infection, including migrants from intermediate and high $\mathrm{HCV}$ prevalence countries (anti-HCV $\geq 2 \%$ and $\geq 5 \%$, respectively). Screening tests to detect the presence of $\mathrm{HCV}$ antibodies performed equally well in all populations. In the laboratory setting or at the point-of-care both are highly sensitive and specific $[6,26]$. DAA therapies are highly efficacious and well tolerated with $>95 \%$ cure rates in a range of populations in different countries [7]. Achieving SVR with HCV therapy is associated with decreased risk and rate of liver disease progression, lower rates of HCC development, and improved survival [27-29,46]. At 2015 costs, DAA based regimens were only moderately cost-effective and as a result less than $30 \%$ of those with HCV had been screened and less than $5 \%$ of all HCV cases had been treated in the EU/EEA in 2015 [2,31]. Migrant populations in the EU/EEA face difficulties accessing care and treatment as a result of numerous barriers at the patient, provider, and health system level $[16,47]$. To reach HCV elimination goals in the EU/EEA dramatic scale up of HCV testing with diagnosis of all groups at HCV risk, including migrants, and linking those found to be positive to care and treatment will be required.

Migrants living in the EU/EEA bear a disproportionate burden of HCV [1,13]. They are older and more likely to have advanced liver disease and hepatocellular carcinoma compared to non-migrants at the time of HCV diagnosis $[17,48,49]$. This is likely due to missed or delayed diagnoses. In a survey in Finland, $63 \%$ of migrants found to be HCV positive had not been previously diagnosed [50]. Seventy percent of these HCV positive migrants had been living in Finland for more than five years. Similarly, in a population based study in Canada, it took a mean of 10 years after arrival for migrants to be diagnosed with HCV [48]. Another Canadian study found that it was cost-effective to screen immigrants for $\mathrm{HCV}$ followed by DAA treatment at an anti-HCV prevalence of $1.9 \%$, which is the mean HCV seroprevalence of migrants living in the EU/EEA [12,13,51]. These data taken together suggest that early screening of migrants based on the HCV prevalence in the country of origin with linkage to care and treatment could prevent liver related sequelae in the migrant population and would be cost-effective. In an ECDC survey, 18 of 21 responding countries had national guidance on HCV testing; however, only six countries (29\%) had guidance on testing migrants for HCV [52]. This highlights an important gap and an opportunity for health promotion among the migrant population.

Migrants face multiple barriers in accessing healthcare services resulting in gaps along all steps of the HCV care continuum [16,53]. Many groups of newly arriving migrants, including asylum seekers and undocumented migrants, lack entitlement to health care in the EU/EEA, thus preventing them from being diagnosed or receiving treatment [54]. Individual barriers include lack of knowledge and awareness of risk factors, fear, and stigma of blood-borne diseases, and socioeconomic, linguistic, and cultural barriers [47,55-57]. Providers are frequently unaware that birth in an HCV endemic country is an important risk factor for HCV. Language and cultural discordance between patients and providers may lead to poor communication and low quality of care $[16,53,58]$. Lack of screening guidelines and programs and the lack of access to interpreters are important health system barriers. Barriers to effective screening and treatment programs may also include lack of political will to address migrant health issues or negative national attitudes toward migrants. Resulting policies may deny migrants the entitlement to health care or prevent the development of migrant-friendly heath care systems [58].

Evidence from primary studies of migrant populations suggests that HCV screening uptake and linkage to care could be improved by implementing decentralized community-based screening strategies, and cooperation with community-based organizations to overcome cultural and language barriers [59-64]. Furthermore, integrated point-of-care testing for HCV, HBV, and HIV increased testing uptake [59,65]. HCV screening and treatment programs for migrants in the EU/EEA will need to be tailored to their specific needs. In addition, it will be necessary to ensure universal access to health care in order to enhance uptake along the entire HCV care continuum. 
The greatest barrier to scaling up HCV treatment in the EU/EEA has been the high cost of therapy, which has decreased dramatically in the past two years [66]. As a result, many countries in the EU/EEA have lifted restrictions and provide more widespread availability of HCV therapy in the region [67]. Dropping prices and simpler short treatment regimens have helped create an opportunity to eliminate $\mathrm{HCV}$ in the EU/EEA. Recent guidance from the WHO has highlighted the need to increase HCV case detection and linkage to HCV care [6]. This includes screening persons originating from countries with an intermediate $(\geq 2 \%)$ and high $(\geq 5 \%) \mathrm{HCV}$ prevalence, which includes many of the migrants living in the EU/EEA. Consideration of existing prevention and control efforts and the capacity of existing systems must also be taken into account [68]. Knowledge of the HCV epidemiology in each EU/EEA Member State will be needed to identify those migrant groups at highest HCV risk, given that the top countries of origin of HCV infected migrants in each country varies (Table S6) [13]. Each country will need to assess their own capacity to increase HCV testing in at risk populations and to ensure that programs are in place that effectively link those with active HCV to care and provide HCV treatment.

\section{Strengths and Limitations}

The major strength of our study is that we used a systematic review process to identify relevant studies and the GRADE methodology to evaluate the certainty of the evidence. Our study had the following limitations. The findings were limited by the low to moderate certainty of the evidence of the included studies. Our study was also limited by the low number of studies reporting on linkage to care for migrants to EU/EEA. Finally, the included cost-effective studies modeled the 2015 cost of DDA therapies. We anticipate however, that HCV screening and treatment will be even more cost-effective given the dramatic decrease in cost of DAA therapy in the EU/EEA since 2015 [66,67].

\section{Conclusions}

In many EU/EEA countries migrants originating from intermediate and high $\mathrm{HCV}$ prevalence countries make up a large proportion of all HCV cases and have poorer liver related outcomes due to delayed diagnosis and treatment. This health disparity is due to the numerous barriers migrants face accessing HCV diagnosis, care, and treatment. Migrant focused programs will need to ensure entitlement to health services and will be most effective if they address linguistic and cultural barriers, are community-based, and integrated with screening for other diseases such as HIV and HBV. Although decreasing HCV costs have made treatment more accessible in the EU/EEA, HCV elimination will only be possible in the region if health systems include and treat migrants for HCV [66].

Supplementary Materials: The following are available online at http:/ /www.mdpi.com/1660-4601/15/9/2013/ s1, Figure S1: Analytic Framework for HCV Screening in Migrants; Table S1. Effectiveness and Cost-effectiveness Search Strategy; Tables S2-S5. Study profile GRADE; Table S6. Chronic HCV burden in migrants: the 10 migrant groups from intermediate/high HCV prevalence countries with the highest number of HCV cases in host EU/EEA countries.

Author Contributions: Conceptualization: C.G., I.V., F.C., R.L.M., and K.P. Methodology: K.P., J.J.M., and R.C. Resources: I.V., F.C., R.L.M., M.P., and T.N., Writing-original draft: C.G., I.M., and B.A. Data curation: C.N.A.C., I.M., A.P., R.L.M., A.T., L.S., and J.J.M. Writing—review \& editing: All authors.

Funding: This work is supported by the European Centre for Disease Prevention and Control (ECDC); FWC No ECDC/2015/016; Specific Contract No 1 ECD.5748. Manish Pareek is supported by the National Institute for Health Research (NIHR Post-Doctoral Fellowship, Manish Pareek, PDF-2015-08-102). The views expressed in this publication are those of the author(s) and not necessarily those of the NHS, the National Institute for Health Research, or the Department of Health. A/Prof Rachael Morton is supported by an Australian NHMRC Sidney Sax Overseas Fellowship \#1054216. The Parker Institute, Bispebjerg, and Frederiksberg Hospital (Christensen) is supported by a core grant from the Oak Foundation (OCAY-13-309).

Conflicts of Interest: C.G. was the first author on five of the infectious disease conditions including hepatitis $\mathrm{C}$ in the Canadian Migrant Health Guidelines; K.P. led the overall guidelines. M.P. reports an institutional grant (unrestricted) for project related to blood-borne virus testing from Gilead Sciences outside the submitted work. I.M., C.N.A.C., B.A., A.P., I.V., F.C., R.M., A.T., L.S., J.J.M., R.C., and T.N. declare no conflicts of interest. The funding sponsors had no role in the design of the study; in the collection, analyses, or interpretation of data; in the writing of the manuscript, and in the decision to publish the results. 


\section{References}

1. European Centre for Disease Prevention and Control. Systematic Review on Hepatitis B and C Prevalence in the EU/EEA; ECDC: Stockholm, Sweden, 2016.

2. Razavi, H.; Robbins, S.; Zeuzem, S.; Negro, F.; Buti, M.; Duberg, A.S.; Roudot-Thoraval, F.; Craxi, A.; Manns, M.; Marinho, R.T.; et al. Hepatitis $C$ virus prevalence and level of intervention required to achieve the WHO targets for elimination in the European Union by 2030: A modelling study. Lancet Gastroenterol. Hepatol. 2017, 2, 325-336. [CrossRef]

3. Mühlberger, N.; Schwarzer, R.; Lettmeier, B.; Sroczynski, G.; Zeuzem, S.; Siebert, U. HCV-related burden of disease in Europe: A systematic assessment of incidence, prevalence, morbidity, and mortality. BMC Public Health 2009, 9, 34. [CrossRef] [PubMed]

4. Mathurin, P. HCV burden in Europe and the possible impact of current treatment. Dig. Liver Dis. 2013, 45 (Suppl. 5), S314-S317. [CrossRef] [PubMed]

5. El Khoury, A.C.; Wallace, C.; Klimack, W.K.; Razavi, H. Economic burden of hepatitis C-associated diseases: Europe, Asia Pacific, and the Americas. J. Med. Econ. 2012, 15, 887-896. [CrossRef] [PubMed]

6. WHO. Guidelines on Hepatitis B and C Testing; World Health Organization: Geneva, Switzerland, 2017.

7. Falade-Nwulia, O.; Suarez-Cuervo, C.; Nelson, D.R.; Fried, M.W.; Segal, J.B.; Sulkowski, M.S. Oral direct-acting agent therapy for hepatitis c virus infection: A systematic review. Ann. Intern. Med. 2017, 166, 637-648. [CrossRef] [PubMed]

8. European Association for the Study of the Liver. EASL Recommendations on Treatment of Hepatitis C 2018. J. Hepatol. 2018, 69, 461-511. [CrossRef] [PubMed]

9. World Health Organisation. Combating Hepatitis B and C to Reach Elimination by 2030; WHO: Geneva, Switzerland, 2016.

10. World Health Organization Regional Office for Europe. Action Plan for the Health Sector Response to Viral Hepatitis in the WHO European Region; WHO/Europe: Copenhagen, Denmark, 2016.

11. World Health Organisation. Global Health Sector Strategy on Viral Hepatitis 2016-2021. Towards Ending Viral Hepatitis; WHO: Geneva, Switzerland, 2016.

12. Falla, A.M.; Ahmad, A.A.; Duffell, E.; Noori, T.; Veldhuijzen, I.K. Estimating the scale of chronic hepatitis $\mathrm{C}$ virus infection in the EU/EEA: A focus on migrants from anti-HCV endemic countries. BMC Infect. Dis. 2018, 18, 42. [CrossRef] [PubMed]

13. European Centre for Disease Prevention and Control. Epidemiological Assessment of Hepatitis B and C among Migrants in the EU/EEA; ECDC: Stockhlom, Sweden, 2016.

14. Pepin, J.; Abou Chakra, C.; Pepin, E.; Nault, V.; Valiquette, L. Evolution of the global burden of viral infections from unsafe medical injections, 2000-2010. PLoS ONE 2014, 9, e99677. [CrossRef] [PubMed]

15. Greenaway, C.; Thu Ma, A.; Kloda, L.A.; Klein, M.; Cnossen, S.; Schwarzer, G.; Shrier, I. The Seroprevalence of Hepatitis C Antibodies in Immigrants and Refugees from Intermediate and High Endemic Countries: A Systematic Review and Meta-Analysis. PLoS ONE 2015, 10, e0141715.

16. Seedat, F.; Hargreaves, S.; Nellums, L.B.; Ouyang, J.; Brown, M.; Friedland, J.S. How effective are approaches to migrant screening for infectious diseases in Europe? A systematic review. Lancet Infect. Dis. 2018. [CrossRef]

17. Chen, W.; Tomlinson, G.; Krahn, M.; Heathcote, J. Immigrant patients with chronic hepatitis C and advanced fibrosis have a higher risk of hepatocellular carcinoma. J. Viral. Hepat. 2012, 19, 574-580. [CrossRef] [PubMed]

18. Pottie, K.; Mayhew, A.; Morton, R.; Greenaway, C.; Akl, E.A.; Rahman, P.; Zenner, D.; Pareek, M.; Tugwell, P.; Welch, V.; et al. Prevention and assessment of infectious diseases among children and adult migrants arriving to the European Union/European Economic Association: A protocol for a suite of systematic reviews for public health and health systems. BMJ Open 2017, 7, e014608. [CrossRef] [PubMed]

19. Moher, D.; Liberati, A.; Tetzlaff, J.; Altman, D.G. Preferred reporting items for systematic reviews and meta-analyses: The PRISMA statement. Ann. Intern. Med. 2009, 151, 264-269. [CrossRef] [PubMed]

20. Woolf, S.; Schunemann, H.J.; Eccles, M.P.; Grimshaw, J.M.; Shekelle, P. Developing clinical practice guidelines: Types of evidence and outcomes; values and economics, synthesis, grading, and presentation and deriving recommendations. Implement. Sci. 2012, 7, 61. [CrossRef] [PubMed] 
21. Owens, D.K.; Whitlock, E.P.; Henderson, J.; Pignone, M.P.; Krist, A.H.; Bibbins-Domingo, K.; Curry, S.J.; Davidson, K.W.; Ebell, M.; Gillman, M.W.; et al. Use of Decision Models in the Development of Evidence-Based Clinical Preventive Services Recommendations: Methods of the U.S. Preventive Services Task Force. Ann. Intern. Med. 2016, 165, 501-508. [CrossRef] [PubMed]

22. Shea, B.J.; Hamel, C.; Wells, G.A.; Bouter, L.M.; Kristjansson, E.; Grimshaw, J.; Henry, D.A.; Boers, M. AMSTAR is a reliable and valid measurement tool to assess the methodological quality of systematic reviews. J. Clin. Epidemiol. 2009, 62, 1013-1020. [CrossRef] [PubMed]

23. Guyatt, G.; Oxman, A.D.; Akl, E.A.; Kunz, R.; Vist, G.; Brozek, J.; Norris, S.; Falck-Ytter, Y.; Glasziou, P.; Jaeschke, R. GRADE guidelines: 1. Introduction-GRADE evidence profiles and summary of findings tables. J. Clin. Epidemiol. 2011, 64, 383-394. [CrossRef] [PubMed]

24. Drummond, M.F.; Sculpher, M.J.; Claxton, K.; Stoddart, G.L.; Torrance, G.W. Methods for the Economic Evaluation of Health Care Programmes, 2nd ed.; Oxford University Press: New York, NY, USA, 1997; p. 396.

25. Alonso-Coello, P.; Oxman, A.D.; Moberg, J.; Brignardello-Petersen, R.; Akl, E.A.; Davoli, A.; Treweek, S.; Mustafa, R.; Vandvik, P.; Meerpohl, J.; et al. GRADE Evidence to Decision (EtD) frameworks: A systematic and transparent approach to making well informed healthcare choices. 2: Clinical practice guidelines. Br. Med. J. 2016, 353, i2089. [CrossRef] [PubMed]

26. Khuroo, M.S.; Khuroo, N.S.; Khuroo, M.S. Diagnostic accuracy of point-of-care tests for hepatitis C virus infection: A systematic review and meta-analysis. PLoS ONE 2015, 10, e0121450. [CrossRef] [PubMed]

27. Kimer, N.; Dahl, E.K.; Gluud, L.L.; Krag, A. Antiviral therapy for prevention of hepatocellular carcinoma in chronic hepatitis C: Systematic review and meta-analysis of randomised controlled trials. BMJ Open 2012, 2, e001313. [CrossRef] [PubMed]

28. Simmons, B.; Saleem, J.; Heath, K.; Cooke, G.S.; Hill, A. Long-Term Treatment Outcomes of Patients Infected With Hepatitis C Virus: A Systematic Review and Meta-analysis of the Survival Benefit of Achieving a Sustained Virological Response. Clin. Infect. Dis. 2015, 61, 730-740. [CrossRef] [PubMed]

29. Public Health Agency of Canada. Treatment for Hepatitis C Virus: A Systematic Review and Meta-Analysis; Canadian Preventative Task Force: Ottawa, ON, Canada, 2016.

30. Yehia, B.R.; Schranz, A.J.; Umscheid, C.A.; Lo Re, V., III. The treatment cascade for chronic hepatitis C virus infection in the United States: A systematic review and meta-analysis. PLoS ONE 2014, 9, e101554. [CrossRef] [PubMed]

31. Deuffic-Burban, S.; Obach, D.; Canva, V.; Pol, S.; Roudot-Thoraval, F.; Dhumeaux, D.; Mathurin, P.; Yazdanpanah, Y. Cost-effectiveness and budget impact of interferon-free direct-acting antiviral-based regimens for hepatitis C treatment: The French case. J. Viral Hepat. 2016, 23, 767-779. [CrossRef] [PubMed]

32. Wong, W.W.; Tu, H.-A.; Feld, J.J.; Wong, T.; Krahn, M. Cost-effectiveness of screening for hepatitis C in Canada. CMAJ 2015, 187, E110-E121. [CrossRef] [PubMed]

33. Najafzadeh, M.; Andersson, K.; Shrank, W.H.; Krumme, A.A.; Matlin, O.S.; Brennan, T.; Avorn, J.; Choudhry, N.K. Cost-effectiveness of novel regimens for the treatment of hepatitis C virus. Ann. Intern. Med. 2015, 162, 407-419. [CrossRef] [PubMed]

34. Chhatwal, J.; Kanwal, F.; Roberts, M.S.; Dunn, M.A. Cost-effectiveness and budget impact of hepatitis C virus treatment with sofosbuvir and ledipasvir in the United States. Ann. Intern. Med. 2015, 162, 397-406. [CrossRef] [PubMed]

35. Younossi, Z.M.; Park, H.; Saab, S.; Ahmed, A.; Dieterich, D.; Gordon, S.C. Cost-effectiveness of all-oral ledipasvir/sofosbuvir regimens in patients with chronic hepatitis $C$ virus genotype 1 infection. Aliment. Pharmacol. Ther. 2015, 41, 544-563. [CrossRef] [PubMed]

36. Rein, D.B.; Wittenborn, J.S.; Smith, B.D.; Liffmann, D.K.; Ward, J.W. The cost-effectiveness, health benefits, and financial costs of new antiviral treatments for hepatitis C virus. Clin. Infect. Dis. 2015, 61, 157-168. [CrossRef] [PubMed]

37. Hagan, L.M.; Sulkowski, M.S.; Schinazi, R.F. Cost analysis of sofosbuvir/ribavirin versus sofosbuvir/simeprevir for genotype 1 hepatitis $C$ virus in interferon-ineligible/intolerant individuals. Hepatology 2014, 60, 37-45. [CrossRef] [PubMed]

38. Saab, S.; Gordon, S.C.; Park, H.; Sulkowski, M.; Ahmed, A.; Younossi, Z. Cost-effectiveness analysis of sofosbuvir plus peginterferon/ribavirin in the treatment of chronic hepatitis $C$ virus genotype 1 infection. Aliment. Pharmacol. Ther. 2014, 40, 657-675. [CrossRef] [PubMed] 
39. Linas, B.P.; Barter, D.M.; Morgan, J.R.; Pho, M.T.; Leff, J.A.; Schackman, B.R.; Horsburgh, C.R.; Assoumou, S.A.; Salomon, J.A.; Weinstein, M.C.; et al. The cost-effectiveness of sofosbuvir-based regimens for treatment of hepatitis c virus genotype 2 or 3 infection. Ann. Intern. Med. 2015, 162, 619-629. [CrossRef] [PubMed]

40. Leidner, A.J.; Chesson, H.W.; Xu, F.; Ward, J.W.; Spradling, P.R.; Holmberg, S.D. Cost-effectiveness of hepatitis $\mathrm{C}$ treatment for patients in early stages of liver disease. Hepatology 2015, 61, 1860-1869. [CrossRef] [PubMed]

41. Brett-Major, D.M.; Frick, K.D.; Malia, J.A.; Hakre, S.; Okulicz, J.F.; Beckett, C.G.; Jagodinski, L.L.; Forgione, M.A.; Gould, P.L.; Harrison, S.A.; et al. Costs and consequences: Hepatitis C seroprevalence in the military and its impact on potential screening strategies. Hepatology 2016, 63, 398-407. [CrossRef] [PubMed]

42. He, T.; Li, K.; Roberts, M.S.; Spaulding, A.C.; Ayer, T.; Grefenstette, J.J.; Chhatwal, J. Prevention of Hepatitis $\mathrm{C}$ by Screening and Treatment in U.S. Prisons. Ann. Intern. Med. 2016, 164, 84-92. [CrossRef] [PubMed]

43. Orkin, C.; Flanagan, S.; Wallis, E.; Ireland, G.; Dhairyawan, R.; Fox, J.; Nandwani, R.; O'Connell, R.; Lascar, M.; Bulman, J.; et al. Incorporating HIV/hepatitis B virus/hepatitis C virus combined testing into routine blood tests in nine UK Emergency Departments: The "Going Viral" campaign. HIV Med. 2016, 17, 222-230. [CrossRef] [PubMed]

44. Selvapatt, N.; Ward, T.; Bailey, H.; Bennett, H.; Thorne, C.; See, L.M.; Tudor-Williams, G.; Thursz, M.; McEwan, P.; Brown, A. Is antenatal screening for hepatitis $C$ virus cost-effective? A decade's experience at a London centre. J. Hepatol. 2015, 63, 797-804. [CrossRef] [PubMed]

45. Ryen, L.; Svensson, M. The Willingness to Pay for a Quality Adjusted Life Year: A Review of the Empirical Literature. Health Econ. 2015, 24, 1289-1301. [CrossRef] [PubMed]

46. Backus, L.I.; Belperio, P.S.; Shahoumian, T.A.; Mole, L.A. Direct-acting antiviral sustained virologic response: Impact on mortality in patients without advanced liver disease. Hepatology 2018. [CrossRef] [PubMed]

47. Owiti, J.A.; Greenhalgh, T.; Sweeney, L.; Foster, G.R.; Bhui, K.S. Illness perceptions and explanatory models of viral hepatitis B \& C among immigrants and refugees: A narrative systematic review. BMC Public Health 2015, 15, 151.

48. Greenaway, C.; Azoulay, L.; Allard, R.; Cox, J.; Tran, V.A.; Abou Chakra, C.N.; Steele, R.; Klein, M. A population-based study of chronic hepatitis $C$ in immigrants and non-immigrants in Quebec, Canada. BMC Infect. Dis. 2017, 17, 140. [CrossRef] [PubMed]

49. Nguyen, L.; Nguyen, M. Systematic review: Asian patients with chronic hepatitis C infection. Aliment. Pharmacol. Ther. 2013, 37, 921-936. [CrossRef] [PubMed]

50. Tiittala, P.; Ristola, M.; Liitsola, K.; Ollgren, J.; Koponen, P.; Surcel, H.M.; Hiltunen-Back, E.; Davidkin, I.; Kivela, P. Missed hepatitis b/c or syphilis diagnosis among Kurdish, Russian, and Somali origin migrants in Finland: Linking a population-based survey to the national infectious disease register. BMC Infect. Dis. 2018, 18, 137. [CrossRef] [PubMed]

51. Wong, W.W.L.; Erman, A.; Feld, J.J.; Krahn, M. Model-based projection of health and economic effects of screening for hepatitis C in Canada. CMAJ Open 2017, 5, E662-E672. [CrossRef] [PubMed]

52. European Centre for Disease Prevention and Control. Hepatitis B and C Testing Activities, Needs, and Priorities in the EU/EEA; ECDC: Stockholm, Sweden, 2017.

53. Greenaway, C.; Makarenko, I.; Tanveer, F.; Janjua, N. Addressing Hepatitis C in the Foreign-Born Population: A key to HCV Elimination in Canada. Can. Liver J. 2018, 1, 34-50. [CrossRef]

54. Noret, I.; Frydryszak, D.; Macherey, A.; Simonnot, N. European Network to Reduce Vulnerabilities in Health. Available online: https:/ / mdmeuroblog.wordpress.com/about/ (accessed on 14 September 2018).

55. Institute of Medicine Committee on the Prevention Control of Viral Hepatitis Infection. Hepatitis and Liver Cancer: A National Strategy for Prevention and Control of Hepatitis B and C; Colvin, H.M., Mitchell, A.E., Eds.; National Academies Press (US), National Academy of Sciences: Washington, DC, USA, 2010.

56. Ferrante, J.M.; Winston, D.G.; Chen, P.H.; de la Torre, A.N. Family physicians' knowledge and screening of chronic hepatitis and liver cancer. Fam. Med. 2008, 40, 345-351. [PubMed]

57. Blondell, S.J.; Kitter, B.; Griffin, M.P.; Durham, J. Barriers and Facilitators to HIV Testing in Migrants in High-Income Countries: A Systematic Review. AIDS Behav. 2015, 19, 2012-2024. [CrossRef] [PubMed]

58. Pareek, M.; Noori, T.; Hargreaves, S.; van den Muijsenbergh, M. Linkage to Care Is Important and Necessary When Identifying Infections in Migrants. Int. J. Environ. Res. Public Health 2018, 15, 1550. [CrossRef] [PubMed] 
59. Fernandez, M.; Manzanares, S.; Jacques, C.; Caylá, J.; Kunkel, J.; Foster, G. Screening for Chronic viral Hepatitis in Migrant Populations-Report on Four HEPscreen Pilot Studies. Available online: http:// hepscreen.eu/wp-content/uploads/2014/12/HEPscreen_Final-WP6-report_Pilot-studies.pdf (accessed on 14 September 2018).

60. Jafferbhoy, H.; Miller, M.H.; McIntyre, P.; Dillon, J.F. The effectiveness of outreach testing for hepatitis C in an immigrant Pakistani population. Epidemiol. Infect. 2012, 140, 1048-1053. [CrossRef] [PubMed]

61. Perumalswami, P.; DiClemente, F.M.; Kapelusznik, L.; Pan, C.; Chang, C.; Friedman, S.L.; Vachon, M.-L.C.; Standen, M.; Khaitova, V.; Factor, S.H.; et al. Hepatitis outreach network (HONE): HBV and HCV screening of ethnic urban populations of New York city with linkage to care. In Hepatology (Baltimore, Md.); John Wiley and Sons Inc.: New York, NY, USA, 2011; Volume 54, pp. 594A-595A.

62. Perumalswami, P.V.; DeWolfe Miller, F.; Orabee, H.; Regab, A.; Adams, M.; Kapelusznik, L.; Aljibawi, F.; Pagano, W.; Tong, V.; Dieterich, D.T.; et al. Hepatitis C screening beyond CDC guidelines in an Egyptian immigrant community. Liver Int. Off. J. Int. Assoc. Stud. Liver 2014, 34, 253-258. [CrossRef] [PubMed]

63. Perumalswami, P.V.; Factor, S.H.; Kapelusznik, L.; Friedman, S.L.; Pan, C.Q.; Chang, C.; Di Clemente, F.; Dieterich, D.T. Hepatitis Outreach Network: A practical strategy for hepatitis screening with linkage to care in foreign-born communities. J. Hepatol. 2013, 58, 890-897. [CrossRef] [PubMed]

64. Zuure, F.R.; Bouman, J.; Martens, M.; Vanhommerig, J.W.; Urbanus, A.T.; Davidovich, U.; van Houdt, R.; Speksnijder, A.G.C.L.; Weegink, C.J.; van den Hoek, A.; et al. Screening for hepatitis B and C in first-generation Egyptian migrants living in the Netherlands. Liver Int. 2013, 33, 727-738. [CrossRef] [PubMed]

65. Bottero, J.; Boyd, A.; Gozlan, J.; Carrat, F.; Nau, J.; Pauti, M.-D.; Rougier, H.; Girard, P.-M.; Lacombe, K. Simultaneous Human Immunodeficiency Virus-Hepatitis B-Hepatitis C Point-of-Care Tests Improve Outcomes in Linkage-to-Care: Results of a Randomized Control Trial in Persons Without Healthcare Coverage. Open Forum Infect. Dis. 2015, 2, ofv162. [CrossRef] [PubMed]

66. Marshall, A.D.; Cunningham, E.B.; Nielsen, S.; Aghemo, A.; Alho, H.; Backmund, M.; Bruggmann, P.; Dalgard, O.; Seguin-Devaux, C.; Flisiak, R.; et al. Restrictions for reimbursement of interferon-free direct-acting antiviral drugs for HCV infection in Europe. Lancet Gastroenterol. Hepatol. 2018, 3, 125-133. [CrossRef]

67. Marshall, A.D.; Pawlotsky, J.M.; Lazarus, J.V.; Aghemo, A.; Dore, G.J.; Grebely, J. The removal of DAA restrictions in Europe-One step closer to eliminating HCV as a major public health threat. J. Hepatol. 2018, in press. [CrossRef] [PubMed]

68. Duffell, E.; Hedrich, D.; Mardh, O.; Mozalevskis, A. Towards Elimination of hepatitsi B and C in European Union and European Economic Area Countries: Monitiroing the World Health Organization's global health sector strategy core indicators and scaling up key interventions. Eurosurveillance 2017, 22, 30476. [CrossRef] [PubMed]

(C) 2018 by the authors. Licensee MDPI, Basel, Switzerland. This article is an open access article distributed under the terms and conditions of the Creative Commons Attribution (CC BY) license (http://creativecommons.org/licenses/by/4.0/). 